\title{
Inventory and distribution of tritium in the oceans in 2016
}

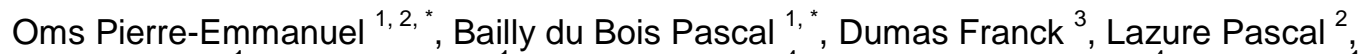 \\ Morillon Mehdi ${ }^{1}$, Voiseux Claire ${ }^{1}$, Le Corre Cedric ${ }^{4}$, Cossonnet Catherine ${ }^{4}$, Solier Luc ${ }^{1}$, \\ Morin Pascal ${ }^{5}$
}

${ }^{1}$ Institut de Radioprotection et de Sûreté Nucléaire, Laboratoire de Radioécologie de CherbourgOcteville, IRSN/PSE-ENV/SRTE/LRC, Rue max Pol Fouchet, BP 10, 50130 Octeville, France

${ }^{2}$ Institut Français de Recherche pour l'Exploitation de la Mer, Laboratoire Océan Côtier, IFREMER/PDG-ODE/LOPS/OC, Centre Bretagne - ZI de la Pointe du Diable, 29280 Plouzané, France

${ }^{3}$ Service Hydrographique et Océanographique de la Maine, SHOM/DOPS/HOM/REC, 13 Rue de

Châtellier, 29200 Brest, France

${ }^{4}$ Institut de Radioprotection et de Sûreté Nucléaire, Laboratoire de Métrologie de la Radioactivité dans I'Environnement, IRSN/PSE-ENV/SAME/LMRE, Bois des Rames - Bâtiment 501, 91400 Orsay, France

${ }^{5}$ Institut Français de Recherche pour l'Exploitation de la Mer, Laboratoire Océan Côtier, IFREMER/PDG-DFO, Centre Bretagne - ZI de la Pointe du Diable, 29280 Plouzané, France

* Corresponding authors : Pierre-Emmanuel Oms, email address : omspe@hotmail.fr ; Pascal Bailly du Bois, email address : pascal.bailly-du-bois@irsn.fr

\begin{abstract}
:
Tritium concentrations in oceans were compiled from the literature, online databases and original measurements in order to determine the global distribution of tritium concentrations according to latitude and depth in all oceans.

The total inventory of tritium decay corrected in 2016 has been estimated using evaluation of the natural and artificial contributions in 23 spatial subdivisions of the total ocean. It is determined equal to $26.8 \pm 14 \mathrm{~kg}$ including $3.8 \mathrm{~kg}$ of cosmogenic tritium. That is in agreement with the total atmospheric input of tritium from nuclear bomb tests and the natural inventory at steady-state estimated from natural production rates in the literature $(27.8-29.3 \mathrm{~kg}$ in the Earth). We confirm the global increase in tritium according to latitude observed in the Northern hemisphere since 1967 with a maximum in the Arctic Ocean. The minimum tritium concentrations observed in the Southern Ocean were close to steady-state with known natural tritium deposition.
\end{abstract}

We focused on the temporal evolution of surface $(0$ to $500 \mathrm{~m})$ tritium concentrations in a selected area of the North Atlantic Ocean $\left(30^{\circ} \mathrm{N}-60^{\circ} \mathrm{N}\right)$ where we found the 2016 concentration to be $0.60 \pm 0.10 \mathrm{TU}$ $(1 \sigma)$. Results showed that in that area, between 1988 and 2013, tritium concentrations: i) decreased faster than the sole radioactive decay, due to a mixing with lower and lateral less concentrated waters, and ii) decreased towards an apparent steady state concentration. The half-time mixing rate of surface waters and the steady state concentration were respectively calculated to be $23 \pm 5$ years $(1 \sigma)$ and $0.38 \pm 0.07 \mathrm{TU}(1 \sigma)$. This apparent steady-state concentration in the North Atlantic Ocean implies a mean tritium deposition of $1870 \pm 345 \mathrm{~Bq} \cdot \mathrm{m}-2(1 \sigma)$, five folds higher than the known inputs (natural, nuclear tests fallout and industrial releases, $\sim 367 \mathrm{~Bq} \cdot \mathrm{m}-2)$ in this area. 


\section{Graphical abstract}

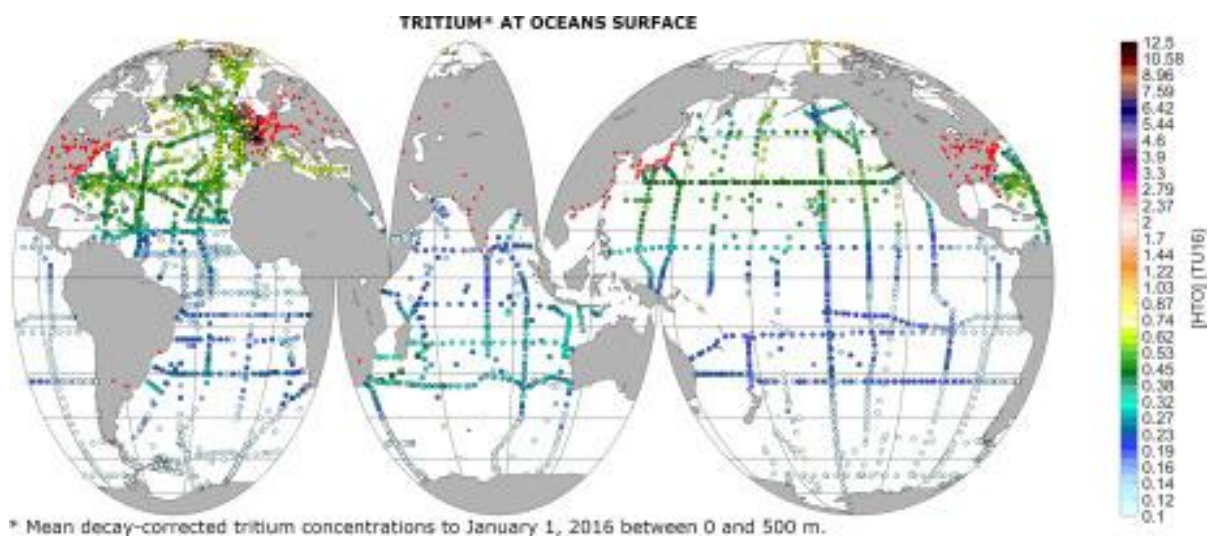

\section{Highlights}

- A database of tritium concentrations available in oceans has been gathered. Inventory of oceanic tritium has been calculated. North-Atlantic Ocean tritium background concentration has been estimated. The Antarctic Ocean is at an apparent steady-state with the natural production rate. The North-Atlantic Ocean concentration exhibits an underestimation of known sources.

Keywords : Radionuclide, Tracer, Database, Background concentration 


\section{Introduction}

Tritium $\left({ }^{3} \mathrm{H}\right)$ is a radioactive isotope of hydrogen with a half-life of $4497 \pm 4$ days ( 12.32 years) (MacMahon 2006). It has been mostly incorporated in the oceans since the late 1950's and the early 1960 's by the fallouts of the atmospheric nuclear tests (Fig. 1), with an estimated atmospheric input of about $520-550 \mathrm{~kg}$ of tritium (Michel, 1976; UNSCEAR, 2000).

Most of the tritium from the nuclear tests was injected into the stratosphere. Tritium remain into the stratosphere for years (mean residence time of 1.6 years (Craig and Lal, 1961)) before crossing the tropopause down into the troposphere (Ehhalt et al., 2002), with fluxes varying temporally and being almost one order of magnitude higher in spring and early summer than in the fall and winter, a 
phenomenon called "spring leak" (Suess, 1969). Once in the troposphere, tritium is rapidly removed, with a mean residence time of about one month (Taylor, 1966).

About $99 \%$ of the atmospheric tritium is in the form of tritiated water molecules (HTO) and thus follows the water cycle. Tritium reaches the ocean via three main processes: i) vapour exchange, ii) precipitation and iii) river runoff. Tritium inputs by vapour exchange exceed inputs by precipitation by about three-folds, (Doney et al., 1992; Koster et al., 1989; Weiss and Roether, 1980). In the case of the North East Atlantic, river runoffs contribute to no more than about $10 \%$ of the tritium deposition (Dreisigacker and Roether, 1978).

The tropospheric circulation in sub-tropical latitudes is composed of two convective cells, the Ferrel and Hadley cell (Fig. 2) converging around $30^{\circ}$ of latitude. The lower circulation of polar cell flows southward from the poles to around $60^{\circ} \mathrm{N}$. Thus, given the location of nuclear explosions (Fig. 1) and the tropospheric circulation in the northern hemisphere, tritium fallouts from atmospheric testing of nuclear weapons are mainly injected in the ocean between $30^{\circ} \mathrm{N}$ and $60^{\circ} \mathrm{N}$ (Bennett, 2002) (Fig. 2). This increase of tritium in ocean according to latitude has been highlighted in the Northern Hemisphere since 1967 (Münnich and Roether, 1967).

In 2016, the inventory of tritium remaining from the fallout of the atmospheric testing of nuclear weapons is estimated to be $22-23.5 \mathrm{~kg}$ (deduced from the radioactive-decay of $520-550 \mathrm{~kg}$ of tritium since 1960). This input greatly exceeds tritium's natural abundance which is around $4.5 \mathrm{~kg}$ of tritium, produced at an average rate of about 3200 atoms. $\mathrm{m}^{-2} \cdot \mathrm{s}^{-1}$ (Masarik and Beer, 2009), i.e. a total of $\sim 258$ g.yr-1 . Tritium is also released in the environment by the civil and military nuclear industries. The global (liquid and atmospheric) annual tritium release from nuclear industries is estimated to be 78 g.yr-1 for the period 1998-2002 (UNSCEAR, 2016).

Since the 1960s, measurements of tritium in the global ocean were performed regularly during largescale observation programs: NAGS (1967-1972), GEOSECS (1972-1976), TTO (1981-1983), WOCE (1990-2002) and GEOTRACES (2010-2020). Scattered observations are also available in the literature 
and supplement the observation acquired during these programs. The distribution and temporal evolution of tritium in the global ocean provide information regarding oceanic ventilation timescales from a few years up to some decades (Andrié et al., 1988; Doney and Jenkins, 1988; Doney et al., 1997; Jenkins, 1987, 1998; Jenkins and Clarke, 1976; Thiele and Sarmiento, 1990). Tritium as HTO is a perfect conservative tracer of water masses and a global compilation of tritium concentrations over a large time scale $(1967-2016)$ and all oceans has never been reported to date. Such a compilation could give valuable insights into inventories, mixing processes between the surface ocean and the deep ocean, as well as into natural and industrial inputs of tritium into the ocean.

We aimed at evaluating the tritium concentration in waters entering the European continental shelf in order to better appreciate the influence of industrial releases at this scale.

In this work, a compilation of global ocean tritium concentrations was carried out. It allows for the estimation of:

(i) the total inventory of tritium in 23 spatial subdivisions throughout the global Ocean;

(ii) the respective contributions of natural and artificial tritium sources in each of the spatial subdivision;

(iii) the tritium distribution and surface waters background level according to latitude and depth in the global ocean;

(iv) the mixing rate of surface water in the North-Atlantic Ocean with the underlying deep waters and the surrounding surface waters;

(v) the apparent steady state concentration in the North Atlantic Ocean (due to continuous natural and anthropic inputs).

In this context, a compilation of tritium concentrations in all oceans is presented with new additional measurements in the North-Atlantic Ocean. The global ocean was divided in boxes (spatial subdivisions) homogeneous in latitude and in depth, in order to highlight the meridional distribution of tritium. Since the North-Atlantic Ocean is the one surrounded by the highest number of nuclear 
facilities releasing tritium worldwide, a particular focus was made on that ocean, for which we report the temporal evolution of tritium concentration.

The European continental shelf includes the major marine tritium sources (reprocessing plants of La Hague in the English Channel and Sellafield in the Irish Sea). Our concern is to evaluate the tritium concentrations in waters entering these areas in order to evaluate the impact of local releases. It requests a good knowledge of the actual North Atlantic waters $\left(30^{\circ} \mathrm{N}-60^{\circ} \mathrm{N}\right)$ entering the European waters (i.e. the Bay of Biscay, the North-Sea and the English Channel).

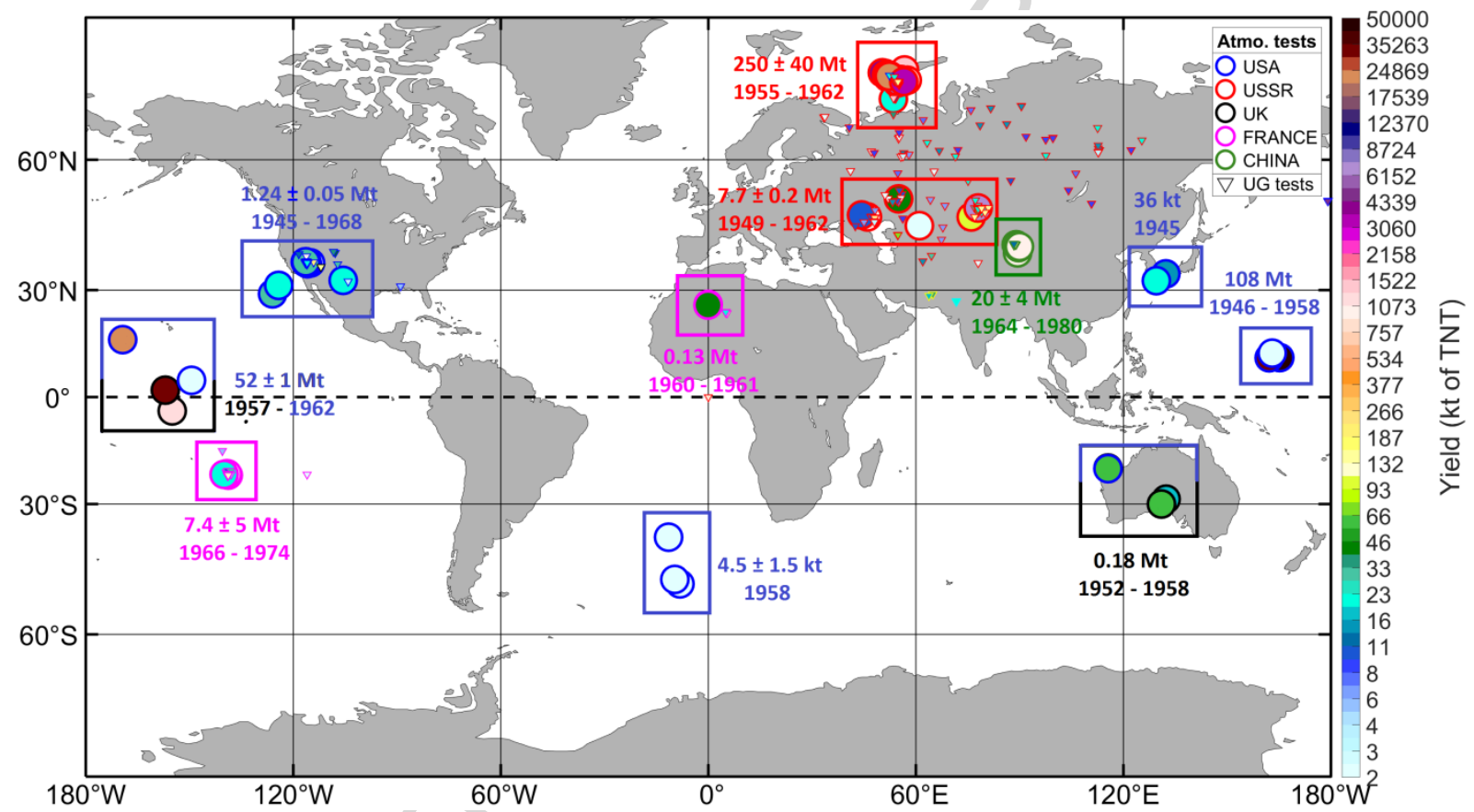

Fig. 1: Map of nuclear explosions between 1945 and 1998. Each marker corresponds to the sum of yield at a same location expressed in kilotons (kt) or megatons (Mt) of trinitrotoluene (TNT). Atmospheric explosions are represented with a circle and underground explosions are represented with a triangle. The edge color of circles corresponds to the state that carried out the explosion. The rectangles represent the sum of yield from atmospheric explosions in a given area for the indicated years. Atmospheric explosions include explosions from balloons, airdrops, rockets, towers, barges, water surface, surface or crater. Underground explosions include explosion from the bottom of drilled or mined vertical holes or shafts, tunnel and gallery, mine, wells in the ground and drilled in the lagoon of atolls. Data extracted from the report of the Swedish National Defence Research Institute (Bergkvist and Ferm, 2000). 


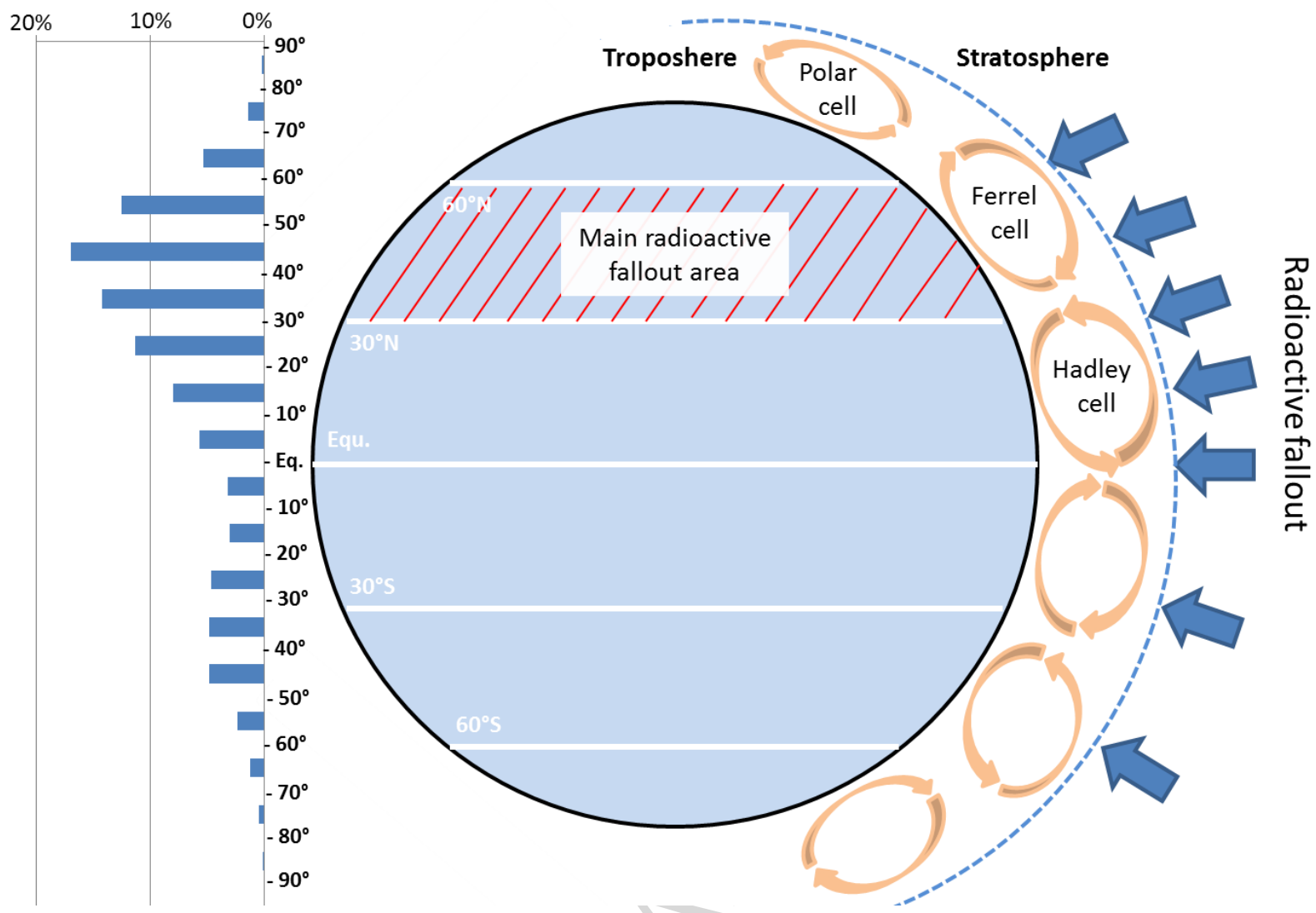

Fig. 2: Latitudinal distribution of global ${ }^{90} \mathrm{Sr}$ deposit at the end of the 1990's (adapted from (Monetti, 1996)) linked with atmospheric dynamics, and the main area of radioactive fallout from atmospheric testing of nuclear weapons. ${ }^{90} \mathrm{Sr}$ is a radionuclide produced along with tritium during the atmospheric testing of nuclear weapons. Its distribution gives an approximation of tritium distribution from the radioactive fallouts of nuclear bomb tests.

\section{Materials and methods}

We tried to gather all the oceanic tritium data available to perform a comprehensive review of tritium distribution in the oceans. Most of these data comes from online databases or publications. We completed that dataset with original measurements that were unpublished to date mostly for recent years and in the North-East Atlantic.

\subsection{Compilation of published data}

Databases and data used for this work were accessed online using the following sources: the GLobal Ocean Data Analysis Project v2 (Olsen et al., 2016), the World Ocean Database (Boyer et al., 2013), Clivar \& Carbon Hydrographic Data Office (CCHDO), GEOTRACES (Schlitzer et al., 2018), North 
Atlantic Gyre Studies (Östlund 1984), Transient Tracers in the Ocean (Östlund and Grall, 1987), TOPOGULF cruise (Andrié et al., 1988), PHYCEMED cruise (Andrié and Merlivat, 1988). Data ranged from year 1967 to year 2016. As the different databases may include the redundant datasets, a comparison between databases was performed in order to remove duplicate tritium measurements. Each tritium measurement in each database was compared with all other measurements in the other tritium databases in terms of time, space, depth, and tritium concentration. Two tritium measurements were considered as identical if they had been performed within less than one day of each other, at a horizontal distance shorter than $30 \mathrm{~km}$, at a depth less than 100 decibars (dbars) and differed in concentrations by less than $0.1 \mathrm{TU}$.

\subsection{Original data}

Between 1996 and 2016, 610 tritium concentrations have been measured by the Laboratoire de Radioécologie de Cherbourg (LRC) during 12 oceanographic campaigns in the western English Channel, the Bay of Biscay, the Atlantic, and the Celtic Sea. They are listed in Table 1.

One liter of sea-water samples were collected using a Niskin bottle, and transferred to a tritium storage bottle. The storage bottle is filled with sea-water and sealed in order to minimize air bubbles and tritium exchange with the atmosphere. Tritium storage bottles were maintained at a temperature of $5^{\circ} \mathrm{C}$, protected from light until measurements.

Two techniques have been used on these samples to determine low-level tritium concentrations:

i) electrolytic enrichment of water samples followed by ${ }^{3} \mathrm{H}$ analysis with gas proportional counting (Östlund et al., 1974). It concerns SMSRB ${ }^{1}$ and $\mathrm{TL}^{2}$ laboratories.

ii) ${ }^{3} \mathrm{He}$ ingrowth and measure by mass spectrometry (Clarke et al., 1976). It concerns LMRE/LRC ${ }^{3}$ and $\mathrm{LSCE}^{4}$ laboratories. Choice of the laboratory depends of their availability over time.

\footnotetext{
${ }^{1}$ SMSRB: Commissariat à l'Energie Atomique (CEA), Service Mixte de Surveillance Radiologique et Biologique de l'homme et de l'environnement

2 TL : Rosenstiel School, The Tritium Laboratory, Miami
} 
Intercomparisons have been performed on same samples between these laboratories to make sure they reported consistent results and could be used interchangeably. Additionally, the unique ${ }^{3} \mathrm{He}$ ingrowth method applied by the LMRE/LRC laboratories annually passed the IARMA Environmental Radioactivity Proficiency Test on the Determination of Tritium in Water to check for its performance. The IARMA tests include the measurement of two low-level tritium samples calibrated at $<0.2 \mathrm{TU}$ and $1.98 \pm 0.07 \mathrm{TU}$. We measure $0.13 \pm 0.03 \mathrm{TU}$ and $2.19 \pm 0.09 \mathrm{TU}$ respectively.

Table 1. Information on original data: dates, area and measurement methods.

\begin{tabular}{|c|c|c|c|c|c|c|}
\hline \multirow{2}{*}{$\begin{array}{l}\text { OCEANOGRAPHIC } \\
\text { CAMPAIGN }\end{array}$} & \multirow[b]{2}{*}{ SHIP } & \multirow{2}{*}{$\begin{array}{l}\text { SAMPLING } \\
\text { DATES } \\
\text { (MM/DD/YYYY) }\end{array}$} & \multirow[b]{2}{*}{ AREA } & \multirow{2}{*}{$\begin{array}{l}\text { Lat }_{\min }-\text { Lat }_{\max } \\
\text { Long }_{\min }-\text { Long }_{\max }\end{array}$} & \multicolumn{2}{|c|}{${ }^{3} \mathrm{H}$ MEASUREMENTS } \\
\hline & & & & & Number & Method and laboratory \\
\hline IRMA & $\begin{array}{c}\text { Côte } \\
\text { d'Aquitaine }\end{array}$ & $\begin{array}{l}11 / 24 / 1996 \\
12 / 11 / 1996\end{array}$ & $\begin{array}{l}\text { West Channel, } \\
\text { South Brittany }\end{array}$ & $\begin{array}{l}48.07^{\circ} \mathrm{N}-50.52^{\circ} \mathrm{N} \\
-6.09^{\circ} \mathrm{W}--1.37^{\circ} \mathrm{W}\end{array}$ & 60 & $\begin{array}{c}\frac{\text { Electrolytic enrichment }}{\text { SMSRB }} \\
\frac{{ }^{3} \mathrm{He} \text { ingrowth }}{\text { LMRE/LRC }}\end{array}$ \\
\hline ARCANE 2 & Thalassa & $\begin{array}{l}08 / 07 / 1997 \\
08 / 22 / 1997\end{array}$ & $\begin{array}{l}\text { East Atlantic } \\
\text { Bay of Biscay }\end{array}$ & $\begin{array}{c}39.45^{\circ} \mathrm{N}-45.58^{\circ} \mathrm{N} \\
-12.75^{\circ} \mathrm{W}--4^{\circ} \mathrm{W}\end{array}$ & 17 & $\frac{\text { Electrolytic enrichment }}{\text { SMSRB }}$ \\
\hline ATMARA & Suroît & $\begin{array}{l}07 / 21 / 1998 \\
08 / 06 / 1998\end{array}$ & $\begin{array}{l}\text { West Channel } \\
\text { Celtic Sea } \\
\text { Bay of Biscay }\end{array}$ & $\begin{array}{c}45.45^{\circ} \mathrm{N}-56.26^{\circ} \mathrm{N} \\
-15^{\circ} \mathrm{W}--3.07^{\circ} \mathrm{W}\end{array}$ & 87 & $\begin{array}{c}\frac{\text { Electrolytic enrichment }}{\text { SMSRB }} \\
\frac{{ }^{3} \mathrm{He} \text { ingrowth }}{\text { LMRE/LRC }}\end{array}$ \\
\hline CIROLANA 2 & Cirolana & $\begin{array}{l}03 / 02 / 2000 \\
04 / 05 / 2000\end{array}$ & $\begin{array}{l}\text { West Channel } \\
\text { Celtic Sea } \\
\text { Bay of Biscay }\end{array}$ & $\begin{array}{c}47.25^{\circ} \mathrm{N}-52.33^{\circ} \mathrm{N} \\
-11.47^{\circ} \mathrm{W}--1.49^{\circ} \mathrm{W}\end{array}$ & 35 & $\frac{\text { Electrolytic enrichment }}{\text { SMSRB }}$ \\
\hline OVIDE & Thalassa & $\begin{array}{l}06 / 12 / 2002 \\
07 / 13 / 2002\end{array}$ & $\begin{array}{l}\text { North-Atlantic } \\
\text { Ocean }\end{array}$ & $\begin{array}{r}40.33^{\circ} \mathrm{N}-59.79^{\circ} \mathrm{N} \\
-42.57^{\circ} \mathrm{W}--9.75^{\circ} \mathrm{W}\end{array}$ & 32 & $\frac{\text { Electrolytic enrichment }}{\mathrm{TL}}$ \\
\hline ASPEX 2009 & Thalassa & $\begin{array}{l}07 / 13 / 2009 \\
07 / 20 / 2009\end{array}$ & Bay of Biscay & $\begin{array}{l}43.98^{\circ} \mathrm{N}-47.79^{\circ} \mathrm{N} \\
-6.01^{\circ} \mathrm{W}--1.52^{\circ} \mathrm{W}\end{array}$ & 36 & $\frac{3 \text { He ingrowth }}{L S C E ; L M R E / L R C}$ \\
\hline ASPEX 2010 & Suroît & $\begin{array}{l}08 / 31 / 2010 \\
09 / 07 / 2010\end{array}$ & Bay of Biscay & $\begin{array}{c}44^{\circ} \mathrm{N}-48.27^{\circ} \mathrm{N} \\
-6.41^{\circ} \mathrm{W}--1.57^{\circ} \mathrm{W}\end{array}$ & 56 & $\frac{{ }^{3} \mathrm{He} \text { ingrowth }}{\mathrm{LMRE} / \mathrm{LRC}}$ \\
\hline ASPEX 2011 & Thalassa & $\begin{array}{l}08 / 07 / 2011 \\
08 / 15 / 2011\end{array}$ & Bay of Biscay & $\begin{array}{l}44^{\circ} \mathrm{N}-47.79^{\circ} \mathrm{N} \\
-6^{\circ} \mathrm{W}--1.52^{\circ} \mathrm{W}\end{array}$ & 36 & $\frac{{ }^{3} \text { He ingrowth }}{\text { LMRE/LRC }}$ \\
\hline TRIMADU & $\begin{array}{l}\text { Marion } \\
\text { Dufresne }\end{array}$ & $\begin{array}{l}04 / 18 / 2013 \\
05 / 11 / 2013\end{array}$ & $\begin{array}{c}\text { Offshore } \\
\text { Gibraltar } \\
\text { S.E. Atlantic } \\
\text { S.W Indian Ocean }\end{array}$ & $\begin{array}{l}-32.36^{\circ} \mathrm{S}-34.94^{\circ} \mathrm{N} \\
-13.22^{\circ} \mathrm{W}-55.5^{\circ} \mathrm{E}\end{array}$ & 12 & $\begin{array}{c}\frac{{ }^{3} \mathrm{He} \text { ingrowth }}{\mathrm{LMRE} / \mathrm{LRC}} \\
\frac{\text { Electrolytic enrichment }}{\mathrm{TL}}\end{array}$ \\
\hline DYNSEDIM & Atalante & $\begin{array}{l}03 / 15 / 2016 \\
03 / 20 / 2016\end{array}$ & Bay of Biscay & $\begin{array}{c}45.9^{\circ} \mathrm{N}-47.93^{\circ} \mathrm{N} \\
-5.38^{\circ} \mathrm{W}--2.68^{\circ} \mathrm{W}\end{array}$ & 27 & $\frac{3 \mathrm{He} \text { ingrowth }}{\text { LMRE/LRC }}$ \\
\hline PELGAS & Thalassa & $\begin{array}{l}05 / 02 / 2016 \\
05 / 27 / 2016\end{array}$ & Bay of Biscay & $\begin{array}{r}43.67^{\circ} \mathrm{N}-47.73^{\circ} \mathrm{N} \\
-5.82^{\circ} \mathrm{W}--1.27^{\circ} \mathrm{W}\end{array}$ & 76 & $\frac{{ }^{3} \text { He ingrowth }}{\text { LMRE/LRC }}$ \\
\hline PLUME & $\begin{array}{l}\text { Côte de la } \\
\text { Manche }\end{array}$ & $\begin{array}{l}05 / 20 / 2016 \\
05 / 29 / 2016\end{array}$ & Bay of Biscay & $\begin{array}{l}44.68^{\circ} \mathrm{N}-48.36^{\circ} \mathrm{N} \\
-5.16^{\circ} \mathrm{W}--1.05^{\circ} \mathrm{W}\end{array}$ & 136 & $\begin{array}{c}\frac{3 \mathrm{He} \text { ingrowth }}{\mathrm{LMRE} / \mathrm{LRC}} \\
\frac{\text { Electrolytic enrichment }}{\mathrm{TL}}\end{array}$ \\
\hline
\end{tabular}

\footnotetext{
${ }^{3}$ LMRE : Institut de Radioprotection et de Sûreté Nucléaire (IRSN), Laboratoire de Métrologie de la Radioactivité dans I'Environnement, in association with the LRC, Laboratoire de Radioécologie de Cherbourg-en-Cotentin.

${ }^{4}$ LSCE : Unité Mixte de Recherche 8212 (UMR 8212), Laboratoire des Sciences du Climat et de l'Environnement
} 


\subsection{Data processing}

All the data obtained online and the newly acquired data from this study were compiled into a single database. It contains a total of 41390 tritium concentrations worldwide, between 1967 and 2016, in all the oceans and at all depths. The compiled database is available online at: https://doi.pangaea.de/10.1594/PANGAEA.892125 (Oms, 2018).

All tritium concentrations in this article are expressed in tritium unit (TU) ( 1 tritium atom per $10^{18}$ hydrogen atoms), with 1TU 119.2 Bq. $\mathrm{m}^{-3}$. The inventories of tritium are expressed in Becquerel (Bq) or $\mathrm{PBq}\left(10^{15} \mathrm{~Bq}\right)$. In order to compare tritium concentrations consistently over time, the tritium concentrations were decay-corrected to a reference date, January 1st, 2016, and expressed as TU16 according to (Eq. 1):

$$
[H T O]_{T U 16}=[H T O]_{T} \times e^{-\lambda\left(T_{2016}-T\right)} \quad \text { (Eq. 1) }
$$

With:

$[H T O]_{T U 16}:$ Decay-corrected tritium concentration, in TU16;

$t_{2016}-t$ : Time elapsed between 01/01/2016 and the sampling date, in s;

$[\mathrm{HTO}]_{t}:$ Tritium concentration at the sampling date, in TU;

$\lambda$ : Radioactive decay constant, in $\mathrm{s}^{-1}, \lambda=\frac{\log (2)}{t_{\frac{1}{2} \text { tritium }}}$, linked to the half-life period $\left(\frac{t_{\frac{1}{2}} \text { tritium }}{2}\right)=$ 12.32 years (MacMahon 2006).

Uncertainties about measurements could not be quantified because a majority of tritium concentrations in the databases were present without their associated measurements errors. The new data reported in the present article are for their part systematically associated with their measurements uncertainties. Uncertainties are ranged between $5 \%$ and $10 \%$ of the measurements. 


\section{Tritium concentrations in the surface ocean}

In order to describe the distribution of tritium in the oceans, the Atlantic, Indian and Pacific oceans were subdivided into 20 boxes of $15^{\circ}$ of latitude each, and 3 boxes corresponding to the Arctic and Southern oceans and the Mediterranean Sea were also considered (Table 2).

Nuclear power plants around the world are mostly located between $30^{\circ} \mathrm{N}$ and $60^{\circ} \mathrm{N}$ on the eastern and western North-Atlantic ocean coasts. In the North-Atlantic, eastern borders of the latitudinal boxes were positioned off the European continental shelves, in order to avoid direct inputs from the Sellafield and La Hague reprocessing plants in boxes II and IV. Indeed releases from the Sellafield and La Hague reprocessing plants are flowing to the Arctic Ocean trough the North Channel (Irish Sea) and the North Sea via the English Channel respectively (Bailly du Bois et al., 1995; Guéguéniat et al., 1997; Kershaw and Baxter, 1995; Nies et al., 1999).

In order to limit the influence of potential hot-spot of tritium coming from non-yet well-mixed tritium releases from nuclear facilities along the Canadian and American coasts which could induce a bias in our calculation, western borders were positioned off the American continental shelf.

In the $30^{\circ} \mathrm{N}$ to $60^{\circ} \mathrm{N}$ latitude range in the North-Atlantic Ocean, the latitudinal boxes were divided in longitude to determine if there was a longitudinal gradient of tritium concentration. Therefore, four boxes encompass the $30^{\circ} \mathrm{N}$ and $60^{\circ} \mathrm{N}$ area in the North Atlantic ocean, box I, II, III and IV.

Tritium concentrations in the global ocean were averaged over the first $500 \mathrm{~m}$ of the water column. This depth range corresponds to a homogeneous tritium distribution in areas II, III and IV in the North Atlantic Ocean $\left(30^{\circ} \mathrm{N}-60^{\circ} \mathrm{N}\right)$ as illustrated on Fig. 3. For comparison, all concentrations in the different boxes were averaged over this depth range. 


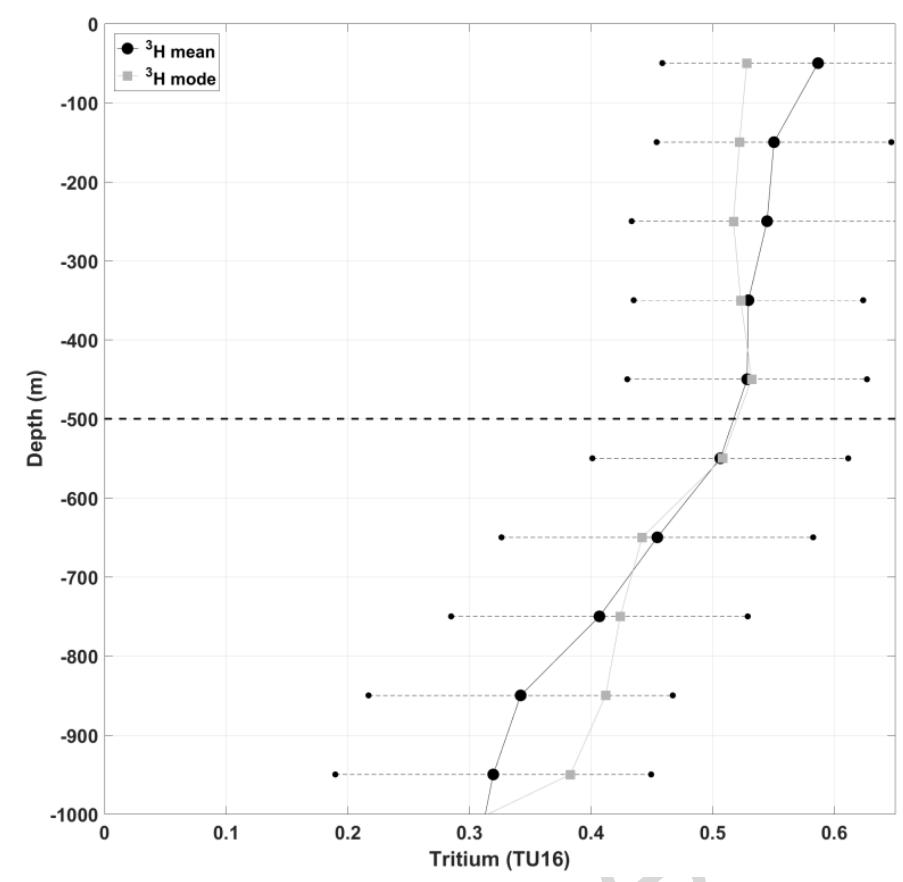

Fig. 3 : Mean decay-corrected tritium concentration (black) with their associated standard deviation and the maximum of the density distribution (mode) (in grey) for each $100 \mathrm{~m}$ layer between $\mathbf{0}$ and $1000 \mathrm{~m}$ depth, in areas II to IV in the North Atlantic Ocean, between years 1972 and 2013.

\section{Inventories of tritium in ocean}

In order to compute the inventory of tritium in all boxes from the surface to the bottom, the GEBCO global 30 arc-second ( $1 \mathrm{~km}$ ), interval grid bathymetry (Weatherall et al. 2015) was used. For each box, the tritium concentrations profiles were reconstructed from the 2016 decay-corrected tritium concentrations using mean concentration of each $100 \mathrm{~m}$ depth layer (some are presented in Annex 2). For each mesh of the bathymetric grid, the integral of the tritium profile was summed starting from the bottom depth to the surface. Results summed for each box are presented in Table 2.

The natural inventory in all boxes was estimated from a cosmogenic production rate equal to 3200 atoms. $\mathrm{m}^{-2} \cdot \mathrm{s}^{-1}$ (Masarik and Beer 2009) which corresponds to a global natural deposition of tritium per unit of surface area $\left(D_{N r}\right)$ equal to $180 \mathrm{~Bq} \cdot \mathrm{m}^{-2} \cdot \mathrm{yr}^{-1}$. We make the assumption that all cosmogenic tritium produced in the atmosphere eventually ends up into the ocean by precipitation, vapour 
exchange and rivers discharges. In order to calculate the tritium deposition rate over an ocean basin it is necessary to take into account its drainage basin area (DBA).

In this way the global natural deposition rate $\left(D_{N r}\right)$ was multiplied by a factor $\left(F_{\text {Area }}\right)$; (Eq. 2), which depends on the drainage basin area DBA of the considered basin ocean (Milliman and Farnsworth 2013, Ludwig et al. 2009). This factor corresponds to the ratio between the DBA plus the basin ocean area (BOA) divided by the BOA (Eq. 2):

$$
F_{\text {Area }}=\frac{D B A+B O A}{B O A}
$$

The DBA and the multiplying factor are indicated Table 2. The DBA of the Southern Ocean has been considered as null because we assume that no recent and significant freshwater comes from the Antarctic continent. The ocean basin natural production rate obtained has been multiplied by the boxes areas in order to calculate a yearly natural input. At steady state, this input amounts to an inventory of 17.28 times the yearly input.

The artificial inventory was deduced from the subtraction between the total and the natural inventory.

\section{Evolution of tritium concentrations in the North-Atlantic Ocean}

We aimed at evaluating the tritium concentration in waters entering the European continental shelf in order to better appreciate the influence of industrial releases at this scale. Indeed an accurate estimate of the tritium concentrations in the North-Atlantic Ocean is lacking to date. In order to determine past and projected future surface tritium concentrations in this area, the temporal evolution of the tritium concentrations was modelled by the non-linear regression of these concentrations between 1988 and 2016.

In contrast to the mean decay-corrected tritium concentrations method which gives a first approximation of the updated tritium concentrations in the ocean, the non-linear regression method takes into account mixing mechanisms which can remove and/or dilute tritium from surface waters 
with time. Additionally, the non-linear regression method highlights a threshold concentration the hereafter called "steady-state concentration". This concentration represents the equilibrium between the tritium atmospheric inputs and the losses resulting from the radioactive decay of tritium contained in the seawater and exchanges with surrounding and deeper water masses. To quantify these mechanisms in the North-Atlantic Ocean, it is necessary to compare the temporal evolution of tritium concentrations in that area with the sole radioactive decay rate of tritium. For this purpose, expected tritium concentrations due to radioactive decay were expressed using the following expression (Eq. 3) and compared with the non-linear regression of the temporal evolution of measured tritium concentrations, expressed using (Eq. 4). The North-Atlantic Ocean was represented by boxes II, III and IV; (see $\S 3.5$ for the reason why area I was not taken into account).

$$
[\mathrm{HTO}]_{t}^{\text {decay }}=[\mathrm{HTO}]_{1988}^{\text {mean }} \times e^{-\lambda\left(t-t_{1988}\right)}
$$

With:

$[\mathrm{HTO}]_{t}^{\text {decay }}$ : Tritium concentration (TU) at time $\mathrm{t}$ (days) taking into account radioactive decay only;

$[H T O]_{1988}^{m e a n}$ : Mean tritium concentration for the initial year 1988 calculated from the measurements in the available dataset for that year, equal to $2.63 \pm 0.18 \mathrm{TU}(1 \sigma, \mathrm{n}=102)$;

$t-t_{1988}$ : Time elapsed since $07 / 26 / 1988$, the date on which the first tritium concentration is available, expressed in days;

$\lambda$ : Radioactive decay constant equal to $1.54 \times 10^{-4}$ days $^{-1}$;

(Eq. 4) is modified from (Eq. 3) to take into account the aforementioned loss and/or dilution of tritium in the area, by introducing i) a factor $F$, representative of the mixing of the surface layer of the ocean in days ${ }^{-1}$, and ii) a constant $\mathrm{N}$, representative of tritium inputs in the area:

$$
[H T O]_{t}=[H T O]_{07 / 26 / 1988}^{\text {init }} \times e^{-\left[(\lambda+F) \times\left(t-t_{1988}\right)\right]}+N \quad \text { (Eq. 4) }
$$

With: 
$[\mathrm{HTO}]_{t}$ : Tritium concentration (TU) at time $\mathrm{t}$ (days) taking into account radioactive decay, mixing processes and steady-state concentration $(\mathrm{N})$;

[HTO $]_{07 / 26 / 1988}^{\text {init }}$ Initial concentration of tritium in areas II, III and IV on 07/26/1988 without $\mathrm{N}$, equal to $2.274 \pm 0.065 \mathrm{TU}$;

$\mathrm{F}=\frac{\log (2)}{t_{\frac{1}{2} m i x}}$ with $t_{\frac{1}{2} \text { mix }}$ is the half-mixing time (days) of surface waters $(0-500 \mathrm{~m})$ with deeper waters and by lateral advection of waters surrounding areas II, III and IV, F $=8.193 \times 10^{-5} \pm$ $1.445 \times 10^{-5}$ days $^{-1}$ and $t_{\frac{1}{2}}$ mix $=8.4602 \times 10^{3}$ days ( 23.18 years).

$N: \mathrm{N}$ is the tritium concentration at steady state when the contribution from nuclear tests will become negligible. It represents an equilibrium between the natural and industrial inputs with the losses due to radioactive decay and mixing of the inventory over $500 \mathrm{~m}$ depth of tritium in the boxes II, III and IV. N is considered as constant in time after 2013, which assumes that industrial releases and natural production will remain constant over time.

The three parameters $[\mathrm{HTO}]_{07 / 26 / 1988}^{\text {init }}, \mathrm{F}$ and $\mathrm{N}$ (Eq. 4), are determined at the same time with the non-linear least-squares estimates of the non-linear model. This analysis was performed using $R$ software (version 3.4.3) and R studio environment with the $n / s$ function of the stats package.

\section{Results and Discussion}

A map of mean decay-corrected tritium distribution in the upper layer $(0-500 \mathrm{~m})$ of the global ocean is shown on Fig. 4. Mean concentrations within each box dividing each ocean with respect to latitude are presented in Table 2. Natural, artificial and total inventories are also presented in Table 2. The artificial inventory for each box is shown Fig. 5 by $\mathrm{m}^{2}$. 


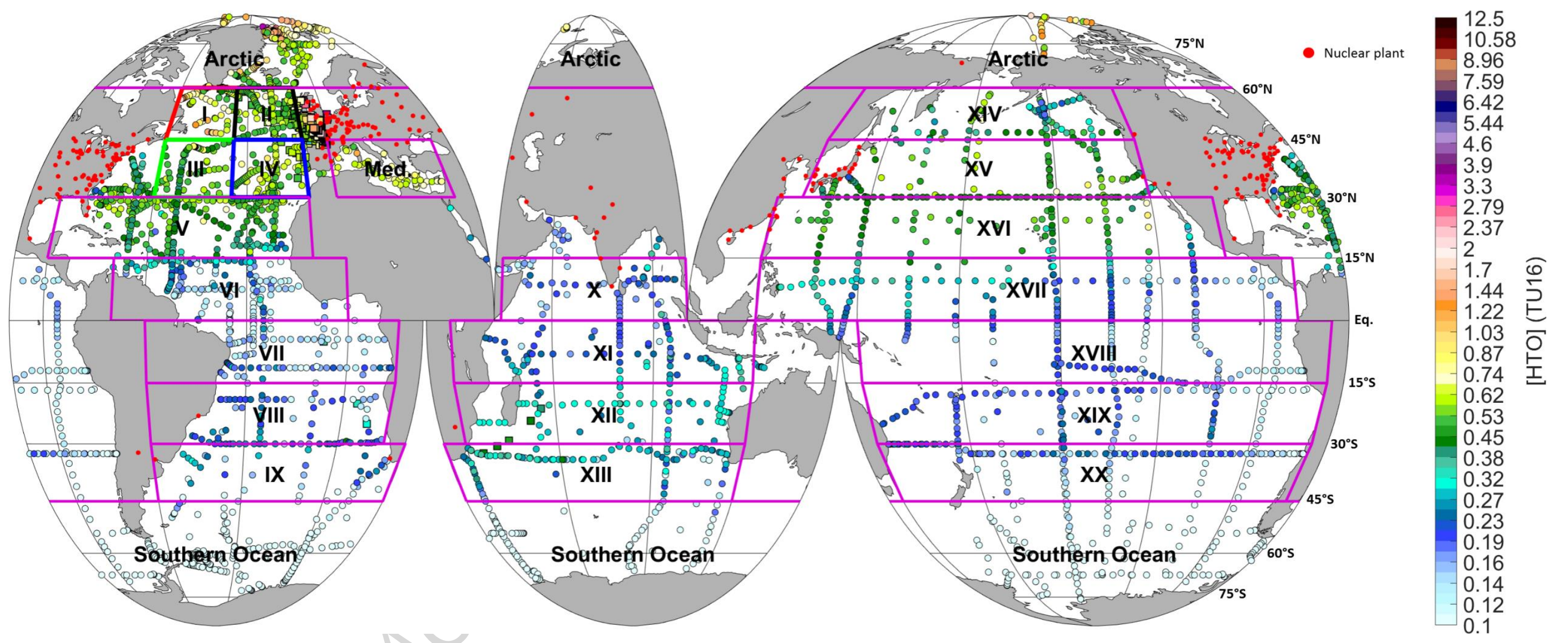

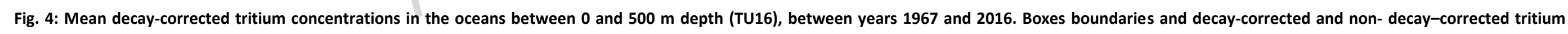

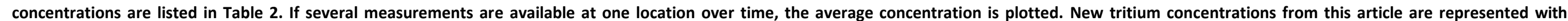
squares, while data compiled from the literature are shown with circles. Nuclear power plants are indicated with red circles (data obtained from http://GlobalEnergyObservatory.org). 
Table 2. Total, natural and artificial tritium inventories and mean tritium concentrations between $0-500 \mathrm{~m}$ between years 1967 and 2016 corrected of radioactive decay (TU16), for all boxes shown on Fig. 4. SD: Standard Deviation. ${ }^{1}$ : from (Milliman and Farnsworth 2013). ${ }^{2}$ : from (Ludwig et al. 2009)

\begin{tabular}{|c|c|c|c|c|c|c|c|c|c|c|c|}
\hline Box & Region & $\begin{array}{c}\text { Lat }_{\min }-\text { Lat }_{\max } \\
\text { Long }_{\min }-\text { Long }_{\max }\end{array}$ & $\begin{array}{l}\text { Box Area } \\
\left(\times 10^{12} \mathrm{~m}^{2}\right)\end{array}$ & $\begin{array}{c}\text { Box Volume } \\
\left(\times 10^{15} \mathrm{~m}^{3}\right)\end{array}$ & $\begin{array}{c}\text { Drainage } \\
\text { Basin Area } \\
\left(\times 10^{12} \mathrm{~m}^{2}\right)^{1} \\
\end{array}$ & $\mathbf{F}_{\text {area }}$ & $\begin{array}{c}\text { Yearly natural } \\
\text { input } \\
\left.\text { (PBq.yr }{ }^{-1}\right)\end{array}$ & $\begin{array}{c}\text { [HTO] } \pm \text { SD } \\
(\mathrm{TU} 16,500 \mathrm{~m})\end{array}$ & $\begin{array}{c}\text { Total } \\
\text { inventory } \\
\text { (PBq) }\end{array}$ & $\begin{array}{c}\text { Natural } \\
\text { inventory } \\
\text { (PBq) }\end{array}$ & $\begin{array}{c}\text { Artificial } \\
\text { inventory } \\
\text { (PBq) }\end{array}$ \\
\hline Arctic & Arctic Ocean & $\begin{array}{l}60^{\circ} \mathrm{N}-90^{\circ} \mathrm{N} \\
0^{\circ} \mathrm{W}-360^{\circ} \mathrm{E}\end{array}$ & 16.9 & 20.3 & 21 & 2.24 & 6.78 & $1.00 \pm 0.91$ & $1293 \pm 637$ & 117 & $1176 \pm 637$ \\
\hline 1 & $\begin{array}{c}\text { North Atlantic Ocean } \\
\text { Labrador Sea }\end{array}$ & $\begin{array}{c}45^{\circ} \mathrm{N}-60^{\circ} \mathrm{N} \\
-60^{\circ} \mathrm{W}--35^{\circ} \mathrm{W} \\
\end{array}$ & 2.6 & 6.6 & \multirow{4}{*}{$\begin{array}{c}24.4 \\
\text { (without } \\
\text { Mediterran } \\
\text { ean DBA) }\end{array}$} & \multirow{4}{*}{1.49} & 0.73 & $0.80 \pm 0.39$ & $415 \pm 108$ & 13 & $402 \pm 108$ \\
\hline II & $\begin{array}{c}\text { North Atlantic Ocean } \\
\text { Celtic Sea }\end{array}$ & $\begin{array}{c}45^{\circ} \mathrm{N}-60^{\circ} \mathrm{N} \\
-35^{\circ} \mathrm{W}--10^{\circ} \mathrm{W} \\
\end{array}$ & 2.8 & 8.4 & & & 0.79 & $0.57 \pm 0.08$ & $408 \pm 95$ & 14 & $395 \pm 95$ \\
\hline III & North Atlantic Ocean & $\begin{array}{c}30^{\circ} \mathrm{N}-45^{\circ} \mathrm{N} \\
-60^{\circ} \mathrm{W}--30^{\circ} \mathrm{W}\end{array}$ & 3.7 & 16.1 & & & 1.03 & $0.50 \pm 0.14$ & $438 \pm 222$ & 18 & $420 \pm 222$ \\
\hline IV & North Atlantic Ocean & $\begin{array}{c}30^{\circ} \mathrm{N}-45^{\circ} \mathrm{N} \\
-30^{\circ} \mathrm{W}--10^{\circ} \mathrm{W}\end{array}$ & 3.7 & 14.1 & & & 1.03 & $0.59 \pm 0.11$ & $349 \pm 142$ & 18 & $331 \pm 142$ \\
\hline Med. & Mediterranean Sea & $\begin{array}{l}30^{\circ} \mathrm{N}-45^{\circ} \mathrm{N} \\
-1^{\circ} \mathrm{W}-37^{\circ} \mathrm{E} \\
\end{array}$ & 2.7 & 4.2 & $5.6^{2}$ & 3.07 & 1.51 & $0.71 \pm 0.19$ & $272 \pm 70$ & 26 & $245 \pm 70$ \\
\hline v & $\begin{array}{c}\text { Sub-Tropical North } \\
\text { Atlantic Ocean }\end{array}$ & $\begin{array}{c}15^{\circ} \mathrm{N}-30^{\circ} \mathrm{N} \\
-90^{\circ} \mathrm{W}--10^{\circ} \mathrm{W} \\
\end{array}$ & 12.3 & 50.1 & \multirow{2}{*}{21.5} & \multirow{2}{*}{1.49} & 3.44 & $0.48 \pm 0.12$ & $705 \pm 425$ & 59 & $646 \pm 425$ \\
\hline VI & $\begin{array}{l}\text { Sub-Equatorial North } \\
\text { Atlantic Ocean }\end{array}$ & $\begin{array}{c}0^{\circ} \mathrm{N}-15^{\circ} \mathrm{N} \\
-70^{\circ} \mathrm{W}-0^{\circ} \mathrm{W}\end{array}$ & 9.2 & 35.8 & & & 2.56 & $0.20 \pm 0.14$ & $235 \pm 172$ & 44 & $191 \pm 172$ \\
\hline VII & $\begin{array}{c}\text { Sub-Equatorial South } \\
\text { Atlantic Ocean }\end{array}$ & $\begin{array}{c}0^{\circ} \mathrm{S}-15^{\circ} \mathrm{S} \\
-60^{\circ} \mathrm{W}-15^{\circ} \mathrm{E}\end{array}$ & 9.3 & 39. & \multirow{3}{*}{12} & \multirow{3}{*}{1.26} & 2.11 & $0.15 \pm 0.08$ & $165 \pm 166$ & 36 & $128 \pm 166$ \\
\hline VIII & $\begin{array}{l}\text { Sub-Tropical South } \\
\text { Atlantic Ocean }\end{array}$ & $\begin{array}{c}15^{\circ} \mathrm{S}-30^{\circ} \mathrm{S} \\
-60^{\circ} \mathrm{W}-15^{\circ} \mathrm{E}\end{array}$ & 9.8 & 40.1 & & & 2.23 & $0.21 \pm 0.12$ & $176 \pm 184$ & 38 & $137 \pm 184$ \\
\hline IX & South Atlantic Ocean & $\begin{aligned} & 30^{\circ} \mathrm{S}-45^{\circ} \mathrm{S} \\
&-60^{\circ} \mathrm{W}-22^{\circ} \mathrm{E} \\
&\end{aligned}$ & 11.4 & 45.8 & & & 2.59 & $0.19 \pm 0.08$ & $189 \pm 103$ & 45 & $145 \pm 103$ \\
\hline$x$ & Indian Ocean & $\begin{array}{c}0^{\circ} \mathrm{N}-15^{\circ} \mathrm{N} \\
45^{\circ} \mathrm{E}-100^{\circ} \mathrm{E}\end{array}$ & 8.9 & 29.2 & \multirow{4}{*}{14} & \multirow{4}{*}{1.19} & 1.91 & $0.18 \pm 0.12$ & $140 \pm 78$ & 33 & $107 \pm 78$ \\
\hline$X I$ & Indian Ocean & $\begin{array}{c}0^{\circ} \mathrm{S}-15^{\circ} \mathrm{S} \\
30^{\circ} \mathrm{E}-120^{\circ} \mathrm{E}\end{array}$ & 13.8 & 53.5 & & & 2.96 & $0.23 \pm 0.11$ & $197 \pm 76$ & 51 & $146 \pm 76$ \\
\hline XII & Indian Ocean & $\begin{array}{c}15^{\circ} \mathrm{S}-30^{\circ} \mathrm{S} \\
30^{\circ} \mathrm{E}-120^{\circ} \mathrm{E}\end{array}$ & 13.4 & 53.9 & & & 2.86 & $0.29 \pm 0.07$ & $377 \pm 72$ & 49 & $327 \pm 72$ \\
\hline XIII & Indian Ocean & $\begin{array}{c}30^{\circ} \mathrm{S}-45^{\circ} \mathrm{S} \\
23^{\circ} \mathrm{E}-120^{\circ} \mathrm{E}\end{array}$ & 13.8 & 54.4 & & & 2.95 & $0.27 \pm 0.08$ & $433 \pm 229$ & 51 & $382 \pm 229$ \\
\hline $\mathrm{XIV}$ & North Pacific Ocean & $\begin{array}{c}45^{\circ} \mathrm{N}-60^{\circ} \mathrm{N} \\
128^{\circ} \mathrm{E}-240^{\circ} \mathrm{E}\end{array}$ & 9.7 & 31.7 & \multirow{2}{*}{15} & \multirow[t]{2}{*}{1.18} & 2.07 & $0.41 \pm 0.16$ & $394 \pm 236$ & 36 & $358 \pm 236$ \\
\hline $\mathrm{XV}$ & North Pacific Ocean & $30^{\circ} \mathrm{N}-45^{\circ} \mathrm{N}$ & 15.6 & 74.8 & & & 3.32 & $0.48 \pm 0.13$ & $636 \pm 240$ & 57 & $578 \pm 240$ \\
\hline
\end{tabular}




\begin{tabular}{|c|c|c|c|c|c|c|c|c|c|c|c|}
\hline & & $128^{\circ} \mathrm{E}-240^{\circ} \mathrm{E}$ & & & & & & & & & \\
\hline $\mathrm{XVI}$ & $\begin{array}{l}\text { Sub-Tropical North } \\
\text { Pacific Ocean }\end{array}$ & $\begin{array}{c}15^{\circ} \mathrm{N}-30^{\circ} \mathrm{N} \\
120^{\circ} \mathrm{E}-260^{\circ} \mathrm{E}\end{array}$ & 22.7 & 105 & & & 4.82 & $0.45 \pm 0.17$ & $872 \pm 413$ & 83 & $788 \pm 413$ \\
\hline XVII & $\begin{array}{l}\text { Sub-Equatorial North } \\
\text { Pacific Ocean }\end{array}$ & $\begin{array}{c}0^{\circ} \mathrm{N}-15^{\circ} \mathrm{N} \\
120^{\circ} \mathrm{E}-280^{\circ} \mathrm{E}\end{array}$ & 28.8 & 124 & & & 6.11 & $0.23 \pm 0.17$ & $337 \pm 202$ & 106 & $231 \pm 202$ \\
\hline XVIII & $\begin{array}{l}\text { Sub-Equatorial South } \\
\text { Pacific Ocean }\end{array}$ & $\begin{array}{c}0^{\circ} \mathrm{S}-15^{\circ} \mathrm{S} \\
150^{\circ} \mathrm{E}-290^{\circ} \mathrm{E}\end{array}$ & 24.0 & 96.8 & \multirow{3}{*}{5} & \multirow{3}{*}{1.05} & 4.54 & $0.15 \pm 0.09$ & $214 \pm 82$ & 78 & $136 \pm 82$ \\
\hline $\mathrm{XIX}$ & South Pacific Ocean & $\begin{array}{c}15^{\circ} \mathrm{S}-30^{\circ} \mathrm{S} \\
150^{\circ} \mathrm{E}-290^{\circ} \mathrm{E}\end{array}$ & 23.5 & 87.4 & & & 4.46 & $0.17 \pm 0.07$ & $268 \pm 113$ & 77 & $191 \pm 113$ \\
\hline$x X$ & South Pacific Ocean & $\begin{array}{c}30^{\circ} \mathrm{S}-45^{\circ} \mathrm{S} \\
150^{\circ} \mathrm{E}-290^{\circ} \mathrm{E}\end{array}$ & 20 & 78.3 & & & 3.76 & $0.15 \pm 0.07$ & $271 \pm 131$ & 65 & $206 \pm 131$ \\
\hline S. Ocean & Southern Ocean & $\begin{array}{c}45^{\circ} \mathrm{S}-90^{\circ} \mathrm{S} \\
0^{\circ} \mathrm{W}-360^{\circ} \mathrm{E}\end{array}$ & 75 & 199 & / & 1.0 & 13.48 & $0.05 \pm 0.04$ & $748 \pm 886$ & 233 & $515 \pm 886$ \\
\hline \multicolumn{3}{|c|}{ TOTAL } & 353 & 1268 & 97 & & $\begin{array}{c}78.04 \\
219 \text { g.yr }\end{array}$ & / & $\begin{array}{l}9531 \pm 5084 \\
\mathbf{2 6 . 8} \pm \mathbf{1 4} \mathbf{~ k g}\end{array}$ & $\begin{array}{l}1347 \\
3.8 \mathrm{~kg}\end{array}$ & $\begin{array}{l}8184 \pm 5084 \\
23.0 \pm 14 \mathbf{~ k g}\end{array}$ \\
\hline
\end{tabular}




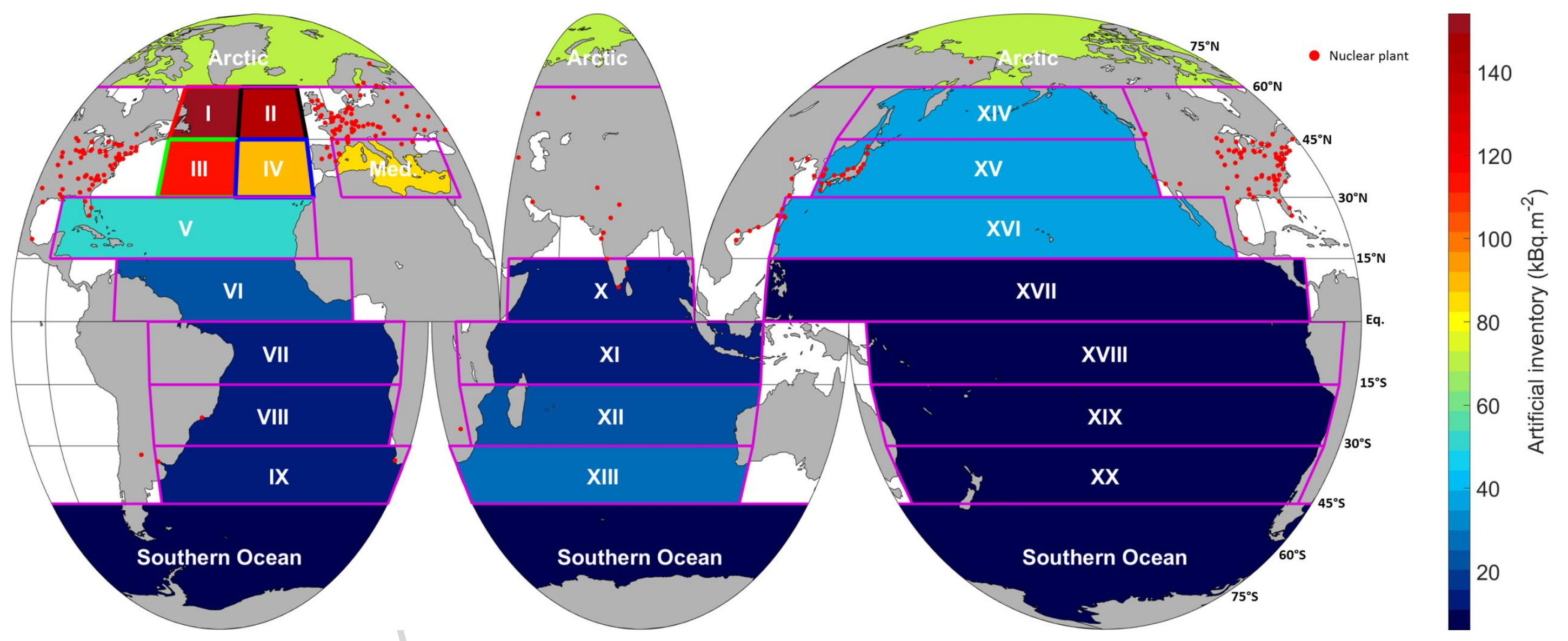

Fig. 5: Artificial inventory of tritium by unit of surface area (kBq. $\mathrm{m}^{-2}$ ) 


\subsection{Inventory of tritium in the ocean}

The total inventory of tritium in the global ocean calculated in all boxes is equal to $26.8 \pm 14$ $\mathrm{kg}$, of which $3.8 \mathrm{~kg}$ are of natural origin and $23.0 \pm 14 \mathrm{~kg}$ artificial derived (Table 2).

This value can be compared to the 2016 inventory of tritium remaining from the nuclear bomb tests estimated from the radioactive decay of 520 - $550 \mathrm{~kg}$ of tritium since 1960 (Michel, 1976; UNSCEAR, 2000), which is equal to $22-23.5 \mathrm{~kg}$. The industrial inventory at steady-state is roughly estimated to $1.3 \mathrm{~kg}$ (from a yearly input of $\sim 78 \mathrm{~g} \cdot \mathrm{yr}^{-1}$ ). The natural inventory at steady-state is estimated equal to $4.5 \mathrm{~kg}$ (from a yearly natural input of $\left.\sim 258 \mathrm{~g} . \mathrm{yr}^{-1}\right)$. It results a total (natural + industrial + nuclear tests) of $27.8-29.3 \mathrm{~kg}$ of tritium in Earth estimated from the literature. These values are in agreement with our estimation of the total and natural inventory in the global ocean ( $90 \%$ of the Earth inventory).

From the difference between the total and the natural inventory, the artificial inventory in each box was deduced (Table 2). Fig. 5, shows the artificial inventory of tritium contained by unit of surface area in each box. The difference between the Northern and the Southern Hemisphere is significant, with higher artificial inventories in the Northern Hemisphere. The higher values of artificial inventory present in the Indian Ocean (boxes XII and XIII) than at the same latitude in the Atlantic (boxes VIII and $(X)$ and in the Pacific Ocean (boxes XIX and XX) may be due to the transport of water masses from the North-Western Pacific via the Indonesian Seas to the Indian Ocean highlighted by (Povinec et al. 2010).

The highest values of artificial inventory by unit of surface area located in the Arctic Ocean, the North-Atlantic Ocean, and in the Mediterranean Sea. It represents a quantity of artificial tritium by $\mathrm{m}^{2}$ more than three folds higher than for the same latitude in the Pacific Ocean. Sections 3.3 and 3.5 discuss these excess. 


\subsection{Latitudinal tritium distribution in the global ocean}

Results of the latitudinal distribution reported on Annex 1 show: (i) about three folds higher tritium concentrations in the Northern Hemisphere $(0.51 \pm 0.50$ TU16, $n=8711$; mean \pm standard deviation, number of samples) than in the Southern Hemisphere ( $0.15 \pm 0.11$ TU16, $n=8176)$, (ii) a global increase of tritium concentrations with latitude in the Northern Hemisphere with especially high tritium concentrations in the Arctic Ocean (1.00 \pm 0.91 TU16, $n=1610)$, (iii) a similar latitudinal distribution of tritium in the Pacific and Atlantic oceans, and (iv) that the lowest tritium concentrations are found in the Southern Ocean $(0.05 \pm 0.04$ TU16, $n=2280)$. Mean decay-corrected tritium concentration in the Mediterranean Sea is equal to $0.71 \pm 0.19$ TU16, $n=312$, which is significantly higher than the concentration in North-Atlantic waters for the same latitude $0.55 \pm 0.13$ TU16, $n=852$ ).

The difference in surface concentrations between the northern hemisphere and the southern hemisphere is directly attributable to the preferential injection of tritium from fallout of nuclear bomb tests into the northern hemisphere (Fig. 1 and Fig. 2). This discrepancy is highlighted by the difference in artificial inventory between the North and the South Hemisphere (Fig. 5). The sum of the artificial tritium inventory in the North - Hemisphere is calculated equal to $\sim 16 \pm 8 \mathrm{Kg}$, and $\sim 7 \pm 6$ kg in the South - Hemisphere (Table 2).

The vertical distribution of tritium presented in Annex 2 shows a decrease of tritium concentrations between 0 and $500 \mathrm{~m}$ depth over all oceans, and homogenous concentrations below $800 \mathrm{~m}$ depth ( 0.02 TU16), except for the Arctic Ocean, the North-Atlantic Ocean and the Mediterranean Sea, which present significantly higher in-depth concentrations $\sim 0.34$ TU16, $~ 0.25$ TU16 and $~ 0.40$ TU16, respectively. 


\subsection{Arctic Ocean}

High tritium concentrations are found in the Arctic Ocean (1.00 \pm 0.91 TU16 in the surface layer above $500 \mathrm{~m}$ depth, Fig. 6). Those high concentrations lead to a high global tritium inventory equal to $1293 \pm 637 \mathrm{PBq}(\sim 3.6 \pm 1.8 \mathrm{~kg})$ (Table 2$)$.

It includes the natural inventory at steady-state estimated to be $117 \mathrm{PBq}(328 \mathrm{~g})$. As for artificial sources we assume that the entirety of the releases between 1952 and 2016 of the European nuclear reprocessing plants of Sellafield and La Hague are introduced in the Arctic Ocean through water transport (Fig. 6). Their total contribution is calculated equal to $203 \mathrm{PBq}(570 \mathrm{~g})$ after radioactive decay. From these values we deduce that the tritium inventory in the Arctic Ocean is composed of $9 \%$ coming from the natural production, $16 \%$ of tritium coming from European nuclear reprocessing plants and $75 \%$ of tritium coming from bomb tests and others unknown sources.

This highly tritiated waters of the upper Arctic Ocean are leaving that enclosed basin to the North Atlantic Ocean via the East Greenland Current (EGC) (Dorsey and Peterson, 1976) and sink into the deep North Atlantic Ocean at convection sites (Doney and Jenkins, 1994) (Fig. 6).

Nowadays, in term of annual inputs the residual input of atmospheric bomb tests can be considered as weak (around $10 \%$ of the natural input). The annual input of cosmogenic tritium is estimated to be $6.78 \mathrm{PBq} . \mathrm{yr}^{-1}\left(19 \mathrm{~g} . \mathrm{yr}^{-1}\right)$. For comparison the mean annual release of European nuclear facilities in the English Channel from 1984 to 2016 is equal to 11.5 PBq.yr-1 $\left(32 \mathrm{~g} \cdot \mathrm{yr}^{-1}\right)$ and is therefore twice as high as the natural flux in the Arctic Ocean. 


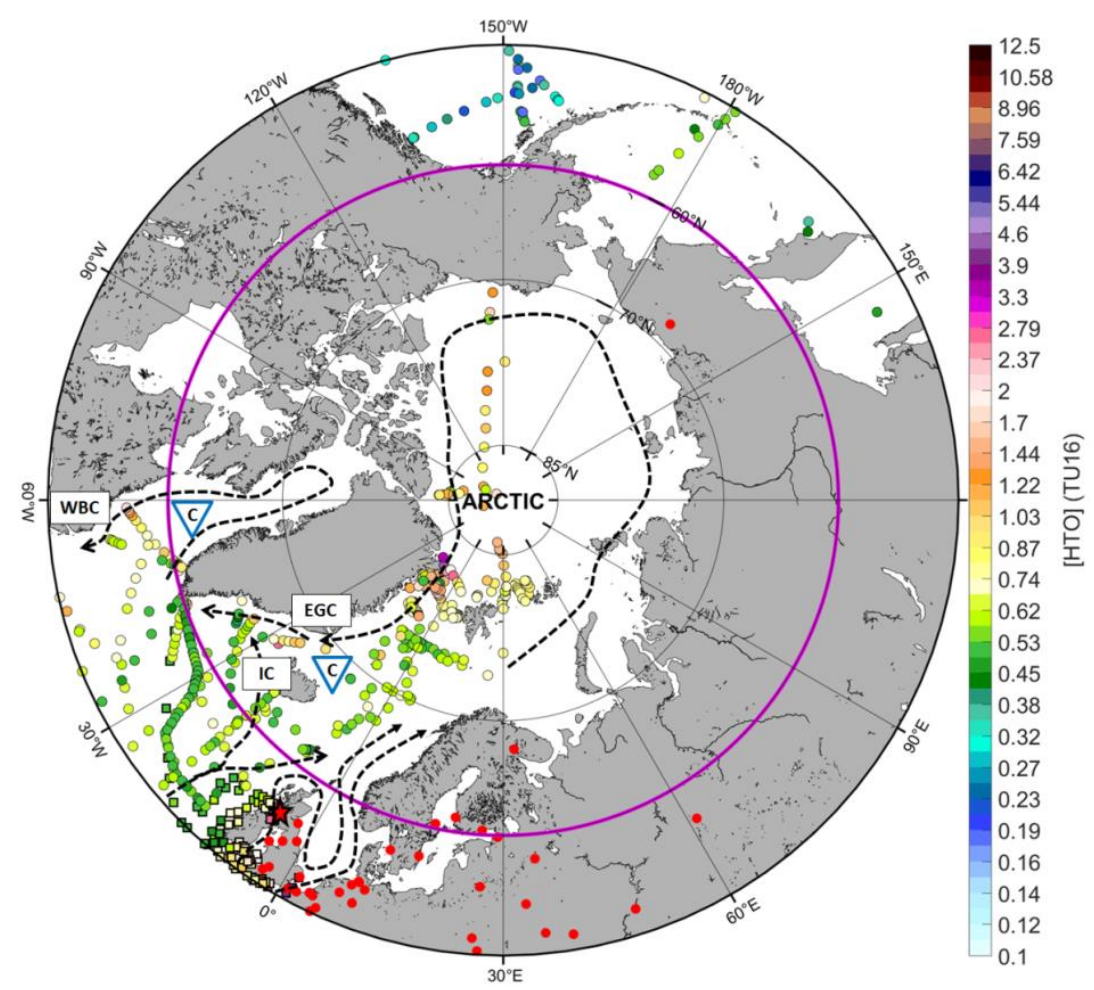

Fig. 6 Mean decay-corrected tritium concentrations (TU16) from 0 to $500 \mathrm{~m}$ between years 1967 and 2016 in the Arctic area and the surrounding areas. A simplified Arctic Ocean circulation scheme, modified from (Karcher et al., 2007) and from (Bailly du Bois and Dumas, 2005) is shown with black dotted arrows. Nuclear Power plants are indicated with red circles, and the reprocessing plant of Sellafield (UK) is indicated with a red star. The boundaries of the Arctic box are indicated with the purple line, at latitude $60^{\circ} \mathrm{N}$. EGC: East Greenland Current, IC: Irminger Current, WBC: western boundary current. The $\mathrm{C}$ in blue triangles indicates the positon of deepwater convection sites.

\subsection{Southern Ocean}

Lowest decay-corrected tritium concentrations measured in the Southern Ocean $(0.05 \pm 0.04$ TU16) and highlighted on Fig. 7 should represent the best estimation of the natural tritium inputs in the upper layer of the oceans $(0-500 \mathrm{~m})$. The most recent mean annual tritium concentration observations were performed over years 2009, 2010 and 2011, with similar tritium concentrations of $0.06 \mathrm{TU}, 0.06 \mathrm{TU}$, and $0.05 \mathrm{TU}$ respectively.

$$
S_{\text {Inv. }}^{\text {S.O. }}=[\mathrm{HTO}]_{500 \mathrm{~m}}^{\text {S.O. }} \times \mathrm{ConvBq} \times \mathrm{Z} \quad \text { (Eq. 5) }
$$

With: 


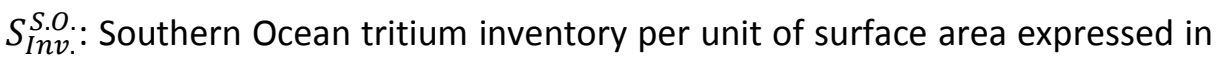
Bq. $\mathrm{m}^{-2}$

$[\mathrm{HTO}]_{500 \mathrm{~m}}^{\mathrm{S} . \mathrm{O}}$ : Decay - corrected or latest measured tritium concentration between 0 and $500 \mathrm{~m}$ depth in the Southern Ocean, equal to 0.05 TU16;

ConvBq: Conversion of TU in Bq. $\mathrm{m}^{-3}, 1 \mathrm{TU} \sim 119.2 \mathrm{~Bq} \cdot \mathrm{m}^{-3}$;

Z: Thickness of tritium mixed layer, equal to $500 \mathrm{~m}$.

Using Eq. 5, we calculate the tritium inventory (over $500 \mathrm{~m}$ ) for the Southern Ocean area to be 2980 Bq. $\mathrm{m}^{-2}$. During one year, this area loses $163 \mathrm{~Bq} \cdot \mathrm{m}^{-2}$ of tritium via radioactive decay. With the hypothesis of a steady-state tritium concentration in Arctic surface waters (over $500 \mathrm{~m}$ ), tritium from natural inputs must counterbalance the loss of tritium due to radioactive decay. The global natural production rate $\left(D_{N r}\right)$ has been previously estimated to be $\sim 180 \mathrm{~Bq} \cdot \mathrm{m}^{-2} \cdot \mathrm{yr}^{-1}$. This natural deposition rate is very close to the one calculated using the annual losses of tritium due to radioactive decay of a water column of $500 \mathrm{~m}$ with a tritium concentration of $0.05 \mathrm{TU}$ (Eq. 5). Therefore, we hypothesize that the Southern Ocean is close to an apparent steady-state with natural tritium inputs and represents a close estimation of the natural tritium inputs in the upper ocean layer $(0-500 \mathrm{~m})$. The total inventory of tritium in the Southern Ocean show a high uncertainty (748 \pm 886 PBq, Table 2) which encompass the estimated natural inventory (233 PBq). This is not in conflict with a near steady-state of the Southern Ocean with the natural inputs. 


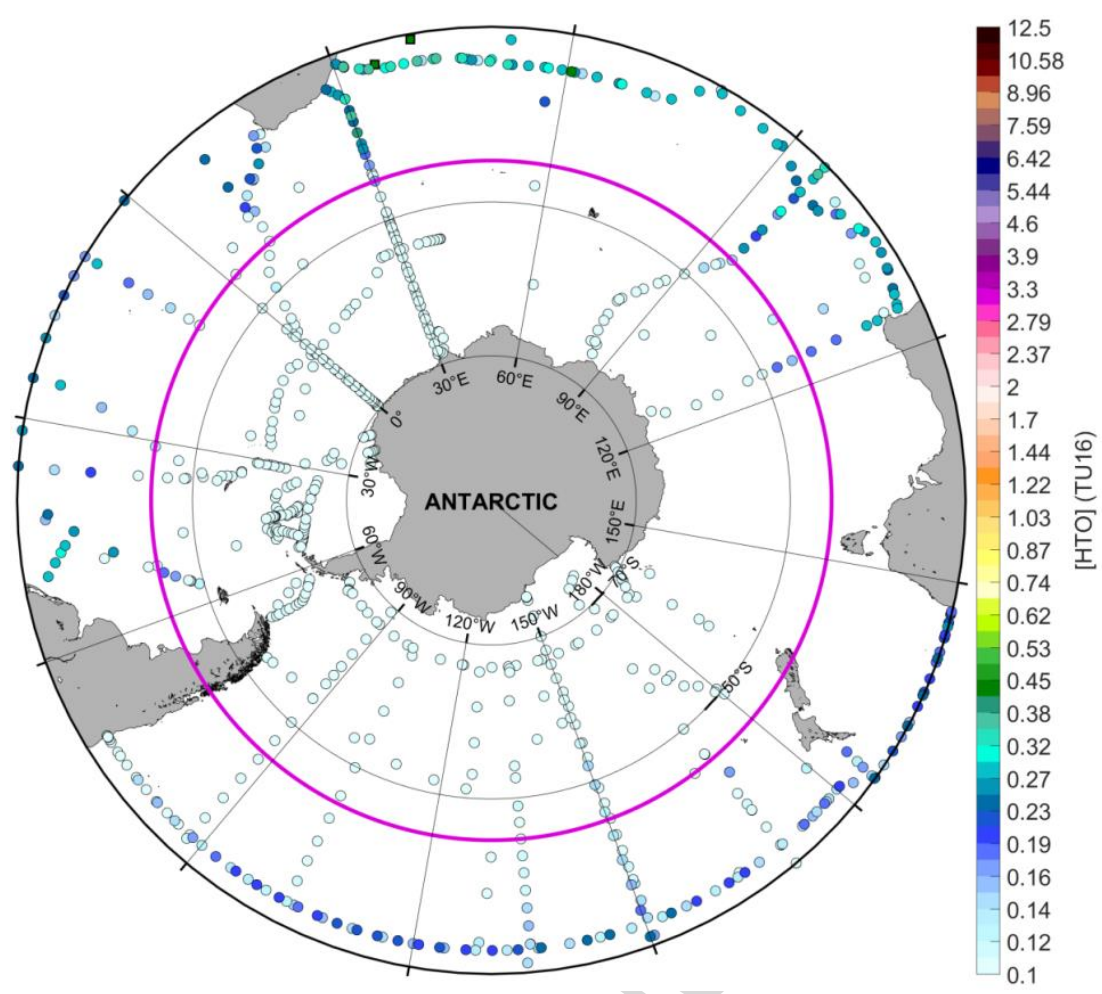

Fig. 7 Mean decay-corrected tritium concentrations (TU16) from 0 to $500 \mathrm{~m}$ between years 1967 and 2016 for the Southern Ocean area and the surrounding areas. Boundaries of the Southern Ocean box are indicated with the purple line, at latitude $40^{\circ} \mathrm{S}$.

\subsection{North-Atlantic Ocean}

The goal of the following sections is to estimate the value of the steady-state concentration in the North-Atlantic Ocean. For this purpose it is necessary firstly to have an overview of the distribution of tritium in this area and secondly to investigate the temporal evolution of these concentrations.

\section{Tritium distribution on the North-Atlantic area (II, III and IV)}

Mean decay-corrected and probability density functions of tritium concentrations of boxes I, II III and IV over $500 \mathrm{~m}$ depth are presented in Annex 3. The maximum of the probability density function called mode which represent the value that have the highest probability to appear is indicated over $500 \mathrm{~m}$ on boxes I, II, III and IV in Annex 3 and plotted each $100 \mathrm{~m}$ between 0 and 1000 m on boxes II, III and IV in Fig. 3. 
Between $45^{\circ} \mathrm{N}$ and $60^{\circ} \mathrm{N}$ in the North-Atlantic Ocean, the mean decay-corrected tritium concentration and the mode of these concentrations over $500 \mathrm{~m}$ depth in the box I (western box), are significantly higher ( $0.80 \pm 0.39$ TU16 and 0.63 TU16 respectively) than in box II (eastern box; 0.57 \pm 0.08 TU16 and 0.52 TU16 respectively) (Annex 3). Conversely, mean tritium concentrations and mode in areas II, III, and IV were found to be similar over first $500 \mathrm{~m}$ depth, around 0.56 TU16 on average [0.37 - 0.82] $(2 \sigma, n=1360)$, with a mode of 0.52 TU16 (Annex 3 and Fig. 3). Subsequently box I will not be taken into account in estimating tritium concentrations in the North Atlantic and only homogeneous boxes II, III and IV are considered by the designation "North-Atlantic Ocean".

The almost homogeneous vertical distribution of tritium concentrations over $500 \mathrm{~m}$ depth on box II, III and IV seen Fig. 3, has determined the comparison depth for all others boxes.

Decay-corrected mean tritium concentration in the surface layer $(0-500 \mathrm{~m})$ of the North Atlantic Ocean $\left(30^{\circ} \mathrm{N}-60^{\circ} \mathrm{N}\right)$ is equal to 0.56 TU16 on average $[0.37-0.82](2 \sigma, n=1360)$.

The water mass transport by the EGC of highly tritiated water from the Arctic Ocean explains the relative high tritium concentrations in box I compared to box II at the same latitude $\left(45^{\circ} \mathrm{N}-60^{\circ} \mathrm{N}\right)$ in the North-Atlantic Ocean. It explains why we decided to discard box I from our estimate of the tritium concentration in 2016 on the North Atlantic surface layer, based on its non-homogenous tritium distribution compared to the other three boxes.

Homogenous concentrations ( 0.56 TU16) in boxes II, III and IV can be linked to the fact that they all are under the influence of the North Atlantic sub-tropical anticyclonic gyre (NASTG, Fig. 8), which likely recirculates and homogenises the tritium concentrations in those areas. Indeed, the Gulf Stream forms the upper west limit of the NASTG, expanding from area III to area II. The east side of the NASTG is formed by the southward recirculation of the Azores current, which becomes the Canary current and feeds the North Equatorial current, thereby forming the South side of the NASTG. The recirculation in the NASTG feeds back into the Gulf Stream through the Caribbean Sea, thereby likely homogenising tritium concentrations between areas II to IV. 
Considering the mean decay-corrected tritium concentration of the Mediterranean Sea $(0.71 \pm 0.19$

TU16, Table 2), one could assume that the Mediterranean Sea is a source of tritium in the NorthAtlantic Ocean, especially for box IV. However Mediterranean waters flow out through the Strait of Gibraltar and sink to around $1000 \mathrm{~m}$, where they spread out across the Atlantic (Piepgras and Wasserburg, 1983). Therefore, tritiated Mediterranean waters do not impact North-Atlantic tritium concentration between 0 and $500 \mathrm{~m}$ depth.

The average tritium concentration in areas II, III and IV reported in the present study $(0.56 \pm 0.12$ TU16) is a first approximation of the 2016 tritium background level in the surface of the NorthAtlantic Ocean. But the decay corrected method does not take into account mixing mechanisms which can remove tritium from surface waters. The regression of the temporal evolution of tritium concentrations would highlight these mechanisms and would give us an estimation of the steadystate concentration.

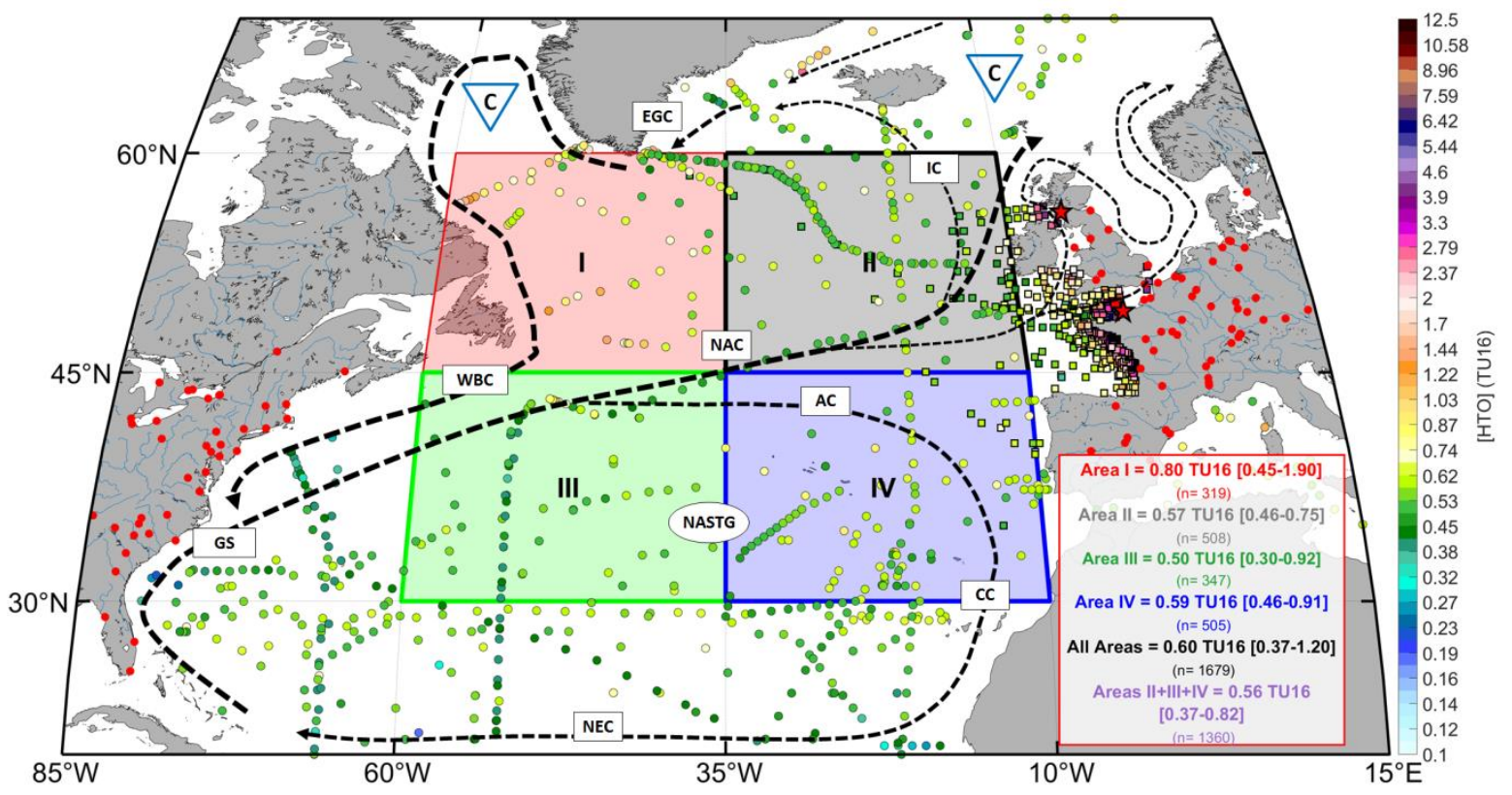

Fig. 8: Distribution of decay-corrected tritium (HTO) concentrations, expressed in TU16 in the North Atlantic surface ocean $(0-500 \mathrm{~m})$, between years 1967 and 2016. Each dot (circle or square) represents the mean HTO concentration between 0-500 m. New tritium concentrations from this article are represented with squares, while data compiled from the literature are shown with circles. Four areas were defined for the purpose of the present study. The mean tritium concentration associated are indicated in the inset, represented as Area $\mathrm{X}=$ mean decay-corrected tritium concentration 
expressed in TU16, with the $95 \%$ confidence Interval $(2 \sigma)$ indicated in brackets, and $n=n u m b e r$ of available measurements. Dotted arrows correspond to simplified surface water hydrography of the North Atlantic currents modified from (Repschläger et al., 2017) and from (Bailly du Bois and Dumas, 2005). Abbreviations are AC: Azores Current, CC: Canary Current, EGC: East Greenland Current, IC: Irminger Current, GS: Gulf Stream; NAC: North-Atlantic Current, NEC: North Equatorial Current, NASTG: North-Atlantic Subtropical Gyre, WBC: Western Boundary Current. Nuclear reprocessing plant of Sellafield (UK) and La Hague (France) are indicated with red stars, while nuclear power plants are represented with red circles. The $\mathrm{C}$ in blue triangles indicates the positon of convection sites where denser waters sink into the deep basins.

\section{Temporal evolution of tritium distribution in the North-Atlantic Ocean}

The temporal evolution of tritium concentrations in boxes II, III and IV, over the first $500 \mathrm{~m}$ beneath the surface are presented on Fig. 9. On this figure, the tritium source function of (Doney and Jenkins, 1988) obtained using the hydrological model of (Weiss et al., 1979), gives an evolution of tritium concentrations in the North-Atlantic Ocean between 1955 and 1981. Tritium concentrations before 1988 are highly variable due to atmospheric testing of nuclear weapons, and were therefore not taken into account in our calculations of (Eq. 3) and (Eq. 4).

The temporal evolution of the mean annual concentrations of tritium, represented by the red dots on Fig. 9, showed that:

(i) tritium concentrations were decreasing at a rate faster than the sole radioactive decay rate of tritium between 1988 and 2013;

(ii) tritium concentrations reach a lower threshold value expressed as $\mathrm{N}$ in (Eq. 4). $\mathrm{N}$ represents, assuming constant natural and artificial releases in the future, the steadystate concentration of these artificial and natural inputs with the loss of tritium due to radioactive decay and mixing with surrounding waters. $\mathrm{N}$ is equal to $0.38 \pm 0.07$ TU. According to the (Eq. 4) we assess the mixing half-time of surface waters in the North Atlantic Ocean, $t_{\frac{1}{2} \text { mix }}=23 \pm 5$ years $(1 \sigma)$, and we estimate the tritium concentration for 
the year 2016 to be $0.60 \pm 0.10 \mathrm{TU}(1 \sigma)$. We obtain for $[H T O]_{07 / 26 / 1988}^{\text {init }}=2.274 \pm 0.065$ $\mathrm{TU} ; t_{\frac{1}{2} \text { mix }}=8.4602 \times 10^{3}$ days ( 23.18 years) and $\mathrm{N}=0.38 \pm 0.07 \mathrm{TU}$.

The calculated mixing half-time, $t_{\frac{1}{2} \text { mix }}=23 \pm 5$ years $(1 \sigma)$, can be compared with previous results based on a two-box mixing model (Weiss et al., 1979) and (Dreisigacker and Roether, 1978). For the first 534 m deep layer of the North Atlantic Ocean, they reported a mixing time of 30 years $\pm 30 \%$ through losses into the deep ocean (i.e. 3.33\%.yr-1). Another estimate reported a ventilation time of 14 years for the first $500 \mathrm{~m}$ deep layer of the north-eastern Atlantic (Andrié et al., 1988). The mixing half-time we estimated for the 0-500 $\mathrm{m}$ top layer of the ocean translates to a rate of mixing of about 3\%.year ${ }^{-1}$ using (Eq. 6), which is comparable to the estimate of (Dreisigacker and Roether, 1978).

$$
R_{\text {mix }}=100 \times\left[1-e^{-F}\right] \text { (Eq. 6) }
$$

With:

$R_{\text {mix }}:$ Annual rate of mixing (\%);

$\mathrm{F}=\frac{\log (2)}{t_{\frac{1}{2} \text { mix }}}$ with $t_{\frac{1}{2} \text { mix }}$ is the mixing half-time (years) of surface waters $(0-500 \mathrm{~m})$ with deeper waters and by lateral advection of waters surrounding areas II, III and IV, F $=0.0299 \pm$ 0.0053 years $^{-1}$ (with $t_{\frac{1}{2} \text { mix }}=23.18$ years); 


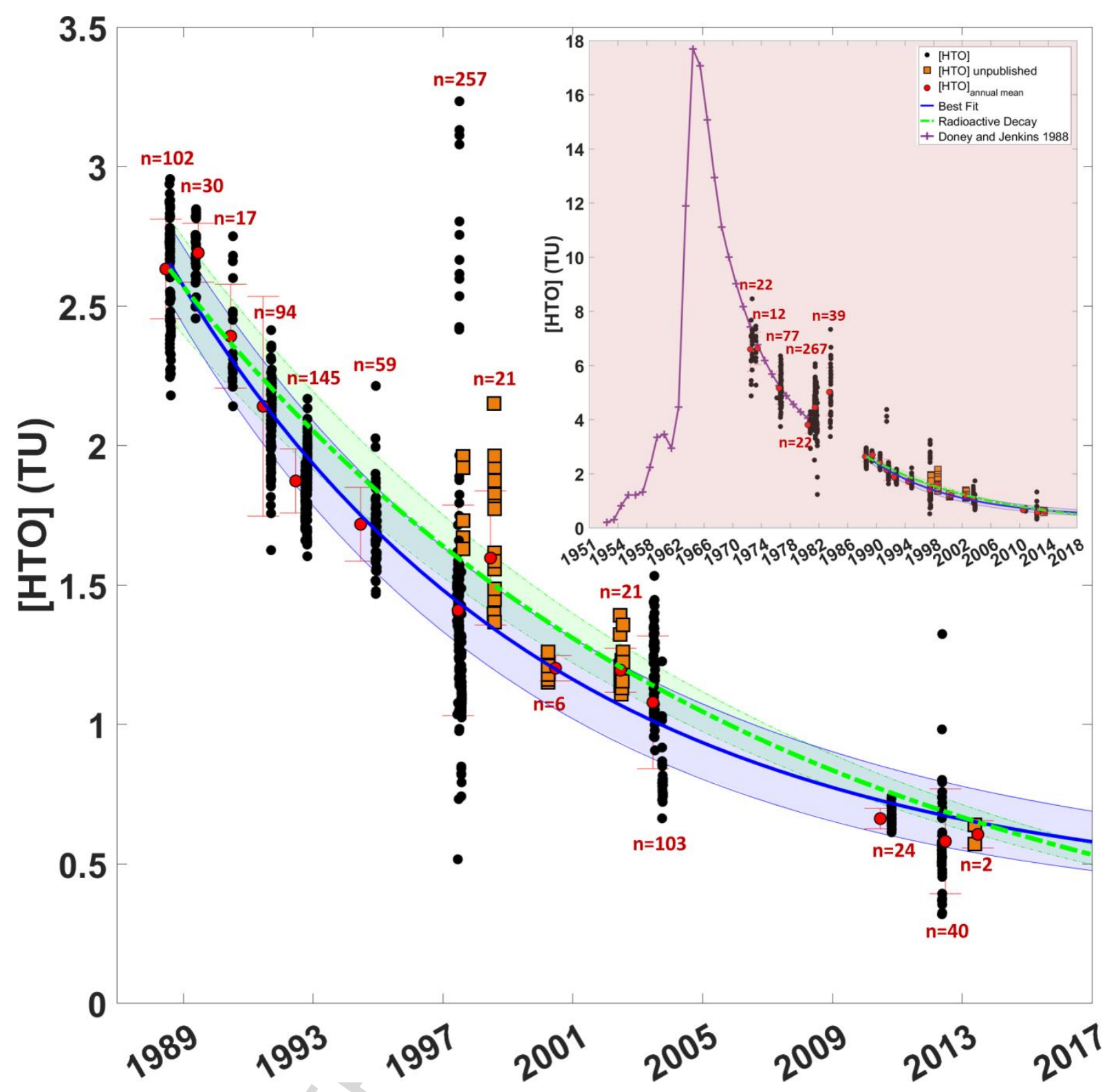

Fig. 9: Temporal evolution of tritium concentrations in boxes II, III and IV between 0-500 $\mathrm{m}$. Tritium concentrations from the literature are represented with black circles and new tritium measurements from the present study are represented with orange squares. The general frame accounts for measurements between 1988 and 2013; the insert shows measurements between 1972 and 2013. In the insert the tritium source function of (Doney and Jenkins, 1988) is represented with a purple line, it gives an evolution of tritium concentrations in the North-Atlantic Ocean between 1952 and 1981. Calculated annual means of tritium concentrations are represented with red circles. The blue line represents the non-linear regression of the tritium concentrations since 1988 (best least square fit for (Eq. 4) with the associated standard deviation (light blue). The green dotted line represents the expected evolution of tritium concentrations due to the sole radioactive decay of the mean tritium concentrations measured in 1988 (Eq. 3). 
In the North-Atlantic Ocean (boxes II, III and IV), the fact that tritium concentrations between 1988 and 2013 were overall decreasing at a faster rate than the sole radioactive is indicative of a loss by mixing with underlying waters and lateral exchange with external surface waters. The steadyconcentration of the North-Atlantic Ocean surface (N, (Eq. 4) means that the loss of tritium due to radioactive decay and mixing must be compensated by an equivalent tritium input.

The loss of tritium during one year of a North-Atlantic water column of $500 \mathrm{~m}$ depth (Z) at a steadystate concentration of $0.38 \mathrm{TU}(\mathrm{N})$ was determined in two successive steps:

i) estimation of the inventory of tritium contained in a water column of $500 \mathrm{~m}$ concentrated at $0.38 \pm 0.07 \mathrm{TU}$, following (Eq. 7);

$$
S_{\text {Inv. }}^{N A}=N \times \operatorname{ConvBq} \times \mathrm{Z} \quad \text { (Eq. 7) }
$$

With:

$S_{I n v}^{N A}:$ Steady-state North-Atlantic tritium inventory per unit of surface area expressed in (Bq. $\left.\mathrm{m}^{-2}\right)$;

N: Steady state concentration for the North-Atlantic Ocean (boxes II, III and IV), equal to $0.38 \pm 0.07 \mathrm{TU}$ (Eq. 4);

ConvBq: Conversion of TU in Bq. $\mathrm{m}^{-3}, 1 \mathrm{TU} \sim 119.2 \mathrm{~Bq} \cdot \mathrm{m}^{-3}$;

Z: Thickness of the mixed tritium concentration layer, equal to $500 \mathrm{~m}$.

It results that the steady-state tritium inventory per unit of surface area $\left(S_{H T O}^{N A}\right)$ over $500 \mathrm{~m}$ depth was equal to $22648 \mathrm{~Bq} \cdot \mathrm{m}^{-2}$.

ii) Calculation of the loss of tritium during one year ( $L$ ) associated to the steady-state tritium inventory $\left(S_{I n v}^{N A}\right)$ by radioactive decay and mixing with deeper and surrounding waters, following (Eq. 8).

$$
L=S_{\text {Inv. }}^{N A}-\left[S_{\text {Inv. }}^{N A} \times e^{-[(\lambda+F) \times T]}\right] \quad \text { (Eq. 8) }
$$

With:

$L$ : Loss of tritium of the steady-state North-Atlantic tritium inventory $\left(S_{I n v}^{N A}\right)\left(\right.$ Bq. $\left.\mathrm{m}^{-2} \cdot \mathrm{yr}^{-1}\right)$; 
We obtain that during one year the loss associated with radioactive decay and mixing with deeper and surrounding waters was: $1870 \pm 345 \mathrm{~Bq} \cdot \mathrm{m}^{-2} \cdot \mathrm{y}^{-1}(\mathrm{~L})$.

This loss of tritium (L) must be compensated by an equivalent input of tritium to maintain the steady state concentration $(\mathrm{N})$ in the North-Atlantic surface waters. In order to estimate the annual tritium input at the surface of the North-Atlantic Ocean, which will be compared to the loss of tritium (L) in this area, two independent methods were applied:

(i) by using measured tritium concentrations in precipitation accounted for in the hydrological model proposed by (Doney et al., 1993);

(ii) by estimation the contribution of known sources over the North-Atlantic surface waters, i.e. the natural production rate (Masarik and Beer, 2009), the reported atmospheric tritium releases from nuclear facilities (UNSCEAR, 2016) and the estimated residual from nuclear bomb tests remaining in the atmosphere (Guétat et al., 2008).

The model of (Doney et al., 1993) computes the atmospheric tritium deposition per unit of surface area. It takes into account tritium inputs by rain and vapour-exchange following (Eq. 9). The tritium concentrations in the rainfalls was measured monthly in 2009 at Valentia, Ireland (IAEA/WMO 2018). Valentia is considered as representative of the North-Atlantic rainfall as it is an island located at the south-western part of Ireland at the Middle East border of the box II. We assume that this island is mainly under influence of oceanic air masses crossing the North Atlantic from west to east under the atmospheric general circulation.

$\mathrm{D}_{a t m}=P C_{p}+\mathrm{E} \frac{h}{(1-h)} \times C_{v}-E \frac{1}{a(1-h)} \times C_{s} \quad$ (Eq. 9)

With:

$\mathrm{D}_{\mathrm{atm}}$ : Atmospheric tritium deposition (Bq. $\left.\mathrm{m}^{-2}\right)$;

P: Precipitation rate $(\mathrm{m}), \sim 1 \mathrm{~m}$ (Dorman and Bourke, 1981);

$\mathrm{C}_{p}$ : Precipitation concentration in $2009\left(\right.$ Bq. $\left.\mathrm{m}^{-3}\right)$, equal to $328 \pm 41$ Bq. $\mathrm{m}^{-3}(1 \sigma)$ Valentia (Ireland) (IAEA/WMO, 2018); 
E: Evaporation rate Precipitation rate in the North Atlantic Ocean (Schmitt et al., 1989);

$\mathrm{h}$ : Water vapour content in $10 \mathrm{~m}$ above sea-level relative to saturation, $\mathrm{h}=0.74$ (Weiss and Roether, 1980);

$\mathrm{C}_{v}$ : Vapour concentration set equal to $\frac{1}{a} \times C_{p}$;

a: Isotopic fractionation factor $0.7 \pm 0.1$ (Doney et al., 1992);

$\mathrm{C}_{s}:$ Tritium concentration at steady-state, equal to $0.38 \pm 0.07 \mathrm{TU}\left(\sim 45 \pm 8 \mathrm{~Bq} \cdot \mathrm{m}^{-3}\right)(1 \sigma)$, from (Eq. 4).

The atmospheric tritium deposition $\left(\mathrm{D}_{\text {atm }}\right)$ obtained is equal to $1413 \pm 170 \mathrm{~Bq} \cdot \mathrm{m}^{-2} \cdot \mathrm{yr}^{-1}$. This value is comparable to the loss of tritium in the surface of the North-Atlantic Ocean at steady-state (L=1870 \pm $345 \mathrm{~Bq} \cdot \mathrm{m}^{-2} \cdot \mathrm{yr} \mathrm{r}^{-1},($ Eq. 8)).

The second method used the known sources of tritium given in the literature in order to calculate the inputs of tritium at the surface of the North-Atlantic Ocean. The known inputs are:

(i) the natural production rate calculated from (Masarik and Beer, 2009) and corrected of the North-Atlantic factor area $\left(F_{\text {Area }},\left(\right.\right.$ Eq. 2)), equal to 268 Bq.m ${ }^{-2}$;

(ii) the industrial releases. Between 1998 and 2002, the global annual releases of tritium to the atmosphere from nuclear facilities ${ }^{5}$ were estimated at 11.7 PBq.yr ${ }^{-1}$ (UNSCEAR, 2016). Considering that almost all atmospheric tritium release occurs in northern hemisphere over a surface area of $2.55 \times 10^{14} \mathrm{~m}^{2}$, the industrial tritium deposition rate is around $69 \mathrm{~Bq} \cdot \mathrm{m}^{-2}$ after correction of the North-Atlantic factor area $\left(F_{\text {Area }},(\right.$ Eq. 2));

(iii) the remaining tritium from nuclear weapons tests. According to an estimation by (Guétat et al., 2008) the tritium released by the atmospheric nuclear weapons tests is still present in 2016 in the atmosphere at an amount of $86 \mathrm{PBq}$. The annual percentage deposition is deduced from the ratio between the natural inventory $(4.5 \mathrm{~kg})$ divided by the yearly natural input $(258 \mathrm{~g})$. It is equal to $~ 6 \% . y \mathrm{r}^{-1}$. With a hypothesis of an equivalent deposition rate of the

\footnotetext{
${ }^{5}$ Nuclear facilities include nuclear reactors, fuel reprocessing plants, waste storage and waste disposal sites.
} 
residuals inventory in the Northern hemisphere, the deposition rate of atmospheric nuclear testing is estimated to be $30 \mathrm{~Bq} \cdot \mathrm{m}^{-2} \cdot \mathrm{yr}^{-1}$ after correction of the North-Atlantic factor area $\left(F_{\text {Area }}\right.$, (Eq. 2)).

It results that a total of $367 \mathrm{~Bq} \cdot \mathrm{m}^{-2} \cdot \mathrm{yr}^{-1}$ of tritium is added in the Northern Hemisphere by known natural, residuals fallout from nuclear weapons testing and industrial deposition. This value is five folds lower than the deposition rate required to maintain a steady-state tritium concentration of 0.38 TU in areas II, III and IV (L=1870 \pm 345 Bq. $\mathrm{m}^{-2} \cdot \mathrm{yr}^{-1}$, (Eq. 8). It is four folds lower than the deposition rate calculated by the hydrological model $\left(\mathrm{D}_{a t m}=1413 \pm 170 \mathrm{~Bq} \cdot \mathrm{m}^{-2} \cdot \mathrm{yr}^{-1}\right.$, (Eq. 9).

In term of budget, the yearly loss of tritium in boxes II, III and IV by radioactive decay and mixing with deeper and surrounding water (L, (Eq. 7)), accounted for a total of $19 \pm 5$ PBq.yr ${ }^{-1}$.

The tritium inputs from known sources (367 Bq. $\mathrm{m}^{-2} \cdot \mathrm{yr}^{-1}$ ) accounted for a yearly input over the whole area of 4 PBq.yr ${ }^{-1}$. Consequently an input of $15 \pm 5$ PBq.yr ${ }^{-1}$ is lacking from the know sources to maintain the steady-state concentration (N, Eq. 4) in areas II, III and IV. For comparison a deposition rate of $367 \mathrm{~Bq} \cdot \mathrm{m}^{-2} \cdot \mathrm{y}^{-1}$ over a water column of $500 \mathrm{~m}$ depth would corresponds to an expected steadystate concentration of $\sim 0.075 \mathrm{TU}$ in the North-Atlantic Ocean.

This discrepancy is also highlighted by the excess of artificial tritium per unit of surface area found in the North-Atlantic Ocean Fig. 5, which suggests higher artificial inputs in the North-Atlantic Ocean.

This discrepancy in North-Atlantic Ocean might be partly explained by the liquid releases from nuclear power plants on western boundaries of the North-Atlantic Ocean ( $\sim 5$ PBq.yr ${ }^{-1}$ which represents the liquid releases from UNSCEAR 2016 without the 11 PBq.yr ${ }^{-1}$ issued from European reprocessing plants), sea-dumping of low-level radioactive waste ( $2 \mathrm{PBq}$ of tritium remaining in 2016 in North-Atlantic Ocean according to IAEA, 2016), and releases of tritium which are not accounted in UNSCEAR 2016 (military and others). As an example, the atmospheric emissions of the 
French military industry of 12 PBq.yr ${ }^{-1}$ between $1968-2007$ are not taken into account (Gazal and Amiard 2010).

\section{Conclusion}

We investigated the tritium distribution in the global ocean using a global compilation of more than 41000 measurements (including 610 new measurements acquired during recent oceanographic campaigns). This compilation (available on https://doi.pangaea.de/10.1594/PANGAEA.892125) provides an overview of tritium over the whole ocean. It allowed us to make quantitative comparisons of natural and artificial tritium inventories according to latitude as well as comparisons of the mean tritium concentrations on the first 500 meters of the water column.

Despite the uncertainties of the results obtained, this study gives an estimation of the inventories of tritium at a global scale. The total oceanic tritium was calculated equal to $26.8 \pm 14 \mathrm{~kg}$, i.e. $3.8 \mathrm{~kg}$ of natural (cosmogenic) tritium and $23 \pm 14 \mathrm{~kg}$ of artificial tritium. This total inventory was found in agreement with previous estimation of the total oceanic stock calculated from the natural inventory at steady-state $(\sim 3.6-4.5 \mathrm{~kg})$ plus the total release of tritium by nuclear bomb tests in the atmosphere since the late 1950's and the early 1960's ( 22-23.5 kg) plus the industrial inventory at steady-state ( $1.3 \mathrm{~kg})$.

The influence of the anthropogenic tritium was found significantly higher in the Northern Hemisphere than in the Southern Hemisphere, in particular in the North-Atlantic Ocean and the Arctic Ocean. In the opposite Hemisphere, in the Southern Ocean, the artificial influence was found weak.

We estimated the contribution of each tritium sources in the Arctic Ocean from the calculation of the total and natural inventory and the knowledge of the liquid tritium releases of the European reprocessing plants. The resulting tritium inventory in Arctic is composed of $9 \%$ coming from the 
natural production, $16 \%$ of tritium coming from European nuclear facilities and $75 \%$ of tritium coming from bomb tests and others unknown sources.

By addressing the temporal evolution of tritium concentrations in the North Atlantic Ocean from 1988 to 2013 , we provide ocean mixing rate and a model describing the evolution of surface tritium concentrations. The half-time mixing rate of surface waters and the steady state concentration were respectively calculated to be $23 \pm 5$ years $(1 \sigma)$ and $0.38 \pm 0.07$ TU $(1 \sigma)$. The 2016 tritium concentration deduced from this temporal evolution is equal to $0.60 \pm 0.10 \mathrm{TU}(1 \sigma)$.

The steady-state tritium concentration calculated in the North-Atlantic Ocean is balanced by the estimated tritium inputs from concentrations measured in the rainfalls. But the tritium inputs estimated from known natural and anthropic deposition in the northern hemisphere $\left(367 \mathrm{~Bq} \cdot \mathrm{m}^{-2}\right)$ is five folds weaker than the required input to maintain this steady-state $\left(1870 \pm 345 \mathrm{~Bq} \cdot \mathrm{m}^{-2}\right)$.

This excess of tritium in the North-Atlantic Ocean is also highlighted by high values of artificial inventory of tritium by unit of surface area in this area compared to the North-Pacific Ocean. We cannot detail the origins of this discrepancy.

Conversely the balance calculated for the Southern Ocean shows an equilibrium between the natural input (180 Bq. $\left.\mathrm{m}^{-2}\right)$ and the inventory of tritium by $\mathrm{m}^{2}$ over $500 \mathrm{~m}$ depth $\left(163 \pm 130 \mathrm{~Bq} \cdot \mathrm{m}^{-2}\right)$.

This study focused on tritium background estimation in the surface waters of the North-Atlantic Ocean, which provides highly needed insights for monitoring the impact of releases from the European nuclear facilities, particularly in the Irish Sea, the Bay of Biscay and the English Channel and accurately determining their contribution.

It could be extended to others part of the oceans where controlled and accidental releases may occur in order to differentiate the open ocean contribution from the local releases.

\section{Acknowledgments}


We thanks to the three anonymous reviewers who provide useful comments that significantly enhance this work.

We are grateful to the crew of the various oceanographic expeditions during which tritium samples were collected, particularly Bernard Le Cann, Pierrick Penven, the Ifremer, SHOM and IPEV team. We would like to thank people and laboratories that helped to measure the original dataset used in the present work. We thank Claire Godinot for her assistance in writing and correcting this article. We thank Dina Okhrimchuk for help in compiling the locations of nuclear power plants worldwide. This work was supported by the Institut de Radioprotection et de Sûreté Nucléaire and the Institut Français de Recherche pour l'Exploitation de la Mer. 
Andrié C., Jean-baptiste P., Merlivat L., 1988. Tritium and helium 3 in the northeastern Atlantic Ocean during the 1983 TOPOGULF cruise. Journal of Geophysical Research: Oceans 93, C10 12511-12524.

Andrié C., Merlivat L., 1988. Tritium in the western Mediterranean Sea during 1981 Phycemed cruise. Deep Sea Research Part A. Oceanographic Research Papers 35, 2 247-267.

http://dx.doi.org/10.1016/0198-0149(88)90039-8

Bailly du Bois P., Salomon J.C., Gandon R., Guéguéniat P., 1995. A quantitative estimate of English Channel water fluxes into the North Sea from 1987 to 1992 based on radiotracer distribution. Journal of Marine Systems 6, 5-6 457-481.

Bailly du Bois P., Dumas F., 2005. Fast hydrodynamic model for medium- and long-term dispersion in seawater in the English Channel and southern North Sea, qualitative and quantitative validation by radionuclide tracers. Ocean Modelling 9, 2 169-210.

http://dx.doi.org/10.1016/j.ocemod.2004.07.004

Bennett B.G., 2002. Worldwide dispersion and deposition of radionuclides produced in atmospheric tests. Health Physics 82, 5 644-655.

Bergkvist N.-O., Ferm R., 2000. Nuclear Explosions 1945-1998. Defence Research Establishment.

Boyer T.P., Antonov J.I., Baranova O.K., Coleman C., Garcia H.E., Grodsky A., Johnson D.R., Locarnini R.A., Mishonov A.V., O'Brien T.D., 2013. World Ocean Database 2013.

Clarke W., Jenkins W.J., Top Z., 1976. Determination of tritium by mass spectrometric measurement of $3 \mathrm{He}$. The International Journal of Applied Radiation and IsotopesVolume 27, Issues 29, Pages 515522. $16 / 0020-708 \times(76) 90082-X$

Craig H., Lal D., 1961. The production rate of natural tritium. Tellus 13, 1 86-105. 
Doney S.C., Jenkins W.J., 1988. The effect of boundary conditions on tracer estimates of thermocline ventilation rates. Journal of Marine Research 46, 4 947-965.

Doney S.C., Glover D.M., Jenkins W.J., 1992. A model function of the global bomb tritium distribution in precipitation, 1960-1986. Journal of Geophysical Research: Oceans 97, C4 5481-5492.

Doney S.C., Jenkins W.J., Östlund H.G., 1993. A tritium budget for the North Atlantic. Journal of Geophysical Research: Oceans 98, C10 18069-18081.

Doney S.C., Jenkins W.J., 1994. Ventilation of the deep western boundary current and abyssal western North Atlantic: Estimates from tritium and 3He distributions. Journal of Physical Oceanography 24, 3 638-659.

Doney S.C., Jenkins W.J., Bullister J.L., 1997. A comparison of ocean tracer dating techniques on a meridional section in the eastern North Atlantic. Deep Sea Research Part I: Oceanographic Research Papers44(44):603-626.

Dorman C.E., Bourke R.H., 1981. Precipitation over the Atlantic Ocean, $30 \mathrm{~S}$ to 70 N. Monthly Weather Review 109, 3 554-563.

Dorsey H.G., Peterson W.H., 1976. Tritium in the Arctic Ocean and East Greenland Current. Earth and Planetary Science Letters 32, 2 342-350. http://dx.doi.org/10.1016/0012-821X(76)90074-1

Dreisigacker E., Roether W., 1978. Tritium and90Sr in North Atlantic surface water. Earth and Planetary Science Letters 38, 2 301-312. http://dx.doi.org/10.1016/0012-821X(78)90104-8

Ehhalt D.H., Rohrer F., Schauffler S., Pollock W., 2002. Tritiated water vapor in the stratosphere: Vertical profiles and residence time. Journal of Geophysical Research: Atmospheres 107, D24. 
Guéguéniat P., Kershaw P., Herrmann J., Bailly du Bois P., 1997. New estimation of La Hague contribution to the artificial radioactivity of Norwegian waters (1992-1995) and Barents Sea (19921997). Science of the Total Environment202, pp.249-266.

Guétat P., Douche C., Hubinois J.C., 2008. Le tritium et l'environnement : sources, mesures et transferts. Radioprotection 43, 4 547-569. http://dx.doi.org/10.1051/radiopro:2008027

Gazal, S. and Amiard, J.C. (2010) Le tritium-Actualité d'aujourd'hui et de demain. Lavoisier (165 pages).

IAEA, 1991. Inventory of Radioactive Material Entering the Marine Environment: Sea Disposal of Radioactive Waste. IAEA TECDOC-588 pp.

IAEA/WMO A., 2018. Global network of isotopes in precipitation. The GNIP database.

Jenkins W.J., Clarke W.B., 1976. The distribution of 3 He in the western Atlantic Ocean, Deep Sea Research and Oceanographic Abstracts. Elsevier,p481-494.

Jenkins W.J., 1987. 3H and 3He in the Beta Triangle: Observations of gyre ventilation and oxygen utilization rates. Journal of Physical Oceanography 17, 6 763-783.

Jenkins W.J., 1998. Studying subtropical thermocline ventilation and circulation using tritium and 3He. Journal of Geophysical Research: Oceans 103, C8 15817-15831.

Karcher M., Kauker F., Gerdes R., Hunke E., Zhang J., 2007. On the dynamics of Atlantic Water circulation in the Arctic Ocean. Journal of Geophysical Research: Oceans 112, C4.

Kershaw P., Baxter A., 1995. The transfer of reprocessing wastes from north-west Europe to the Arctic. Deep Sea Research Part II: Topical Studies in OceanographyVolume 42, Issues 46, Pages 14131448. 16/0967-0645(95)00048-8 
Koster R.D., Broecker W.S., Jouzel J., Suozzo R.J., Russell G.L., Rind D., White J.W.C., 1989. The global geochemistry of bomb-produced tritium: General circulation model compared to available observations and traditional interpretations. Journal of Geophysical Research: Atmospheres 94, D15 18305-18326.

Ludwig, W., Dumont, E., Meybeck, M. and Heussner, S. (2009) River discharges of water and nutrients to the Mediterranean and Black Sea: major drivers for ecosystem changes during past and future decades? Progress in Oceanography 80(3), 199-217.

MacMahon, D. (2006) Half-life evaluations for 3H, 90Sr, and 90Y. Applied radiation and isotopes 64(10-11), 1417-1419.

Masarik J., Beer J., 2009. An updated simulation of particle fluxes and cosmogenic nuclide production in the Earth's atmosphere. Journal of Geophysical Research: Atmospheres 114, D11.

Michel R.L., 1976. Tritium inventories of the world oceans and their implications. Nature 263, 5573 103.

Milliman, J.D. and Farnsworth, K.L. (2013) River discharge to the coastal ocean: a global synthesis, Cambridge University Press.

Monetti M.A., 1996. Worldwide deposition of strontium-90 through 1990. USDOE Environmental Measurements Lab., New York, NY (United States).

Münnich K.O. and Roether W., 1967. Transfer of bomb $14 \mathrm{C}$ and tritium from the atmosphere to the ocean. Internal mixing of the ocean on the basis of tritium and $14 \mathrm{C}$ profiles.

Nies H., Harms I.H., Karcher M.J., Dethleff D., Bahe C., 1999. Anthropogenic radioactivity in the Arctic Ocean -- review of the results from the joint German project. Science of the Total Environment. Volume 237-238, Pages 231-191. 
Olsen A., Key R.M., Van Heuven S., Lauvset S.K., Velo A., Lin X., Schirnick C., Kozyr A., Tanhua T., Hoppema M., 2016. The Global Ocean Data Analysis Project version 2 (GLODAPv2)-an internally consistent data product for the world ocean. Earth System Science Data 8, 2297.

[dataset] Oms P.-E., 2018. Tritium in oceans: a compilation, in: PANGAEA (Ed.).

https://doi.org/10.1594/PANGAEA.892125

Östlund H.G., Dorsey H.G., Rooth C.G., 1974. Geosecs North Atlantic radiocarbon and tritium results. Earth and Planetary Science Letters 23, 169-86. http://dx.doi.org/10.1016/0012-821X(74)90033-8

Östlund H.G., 1984. NAGS TRITIUM: North Atlantic Gyre Studies and Associated Projects. University of Miami, Rosenstiel School of Marine and Atmospheric Science.

Östlund H.G., Grall C., 1987. TTO NORTH AND TROPICAL ATLANTIC TRITIUM AND RADIOCARBON.

Piepgras D.J., Wasserburg G.J., 1983. Influence of the Mediterranean outflow on the isotopic composition of neodymium in waters of the North Atlantic. Journal of Geophysical Research: Oceans 88, C10 5997-6006.

Povinec, P.P., Lee, S.H., Kwong, L.L.W., Oregioni, B., Jull, A.J.T., Kieser, W.E., Morgenstern, U. and Top, Z. (2010) Tritium, radiocarbon, 90Sr and 1291 in the Pacific and Indian Oceans. Nuclear Instruments and Methods in Physics Research Section B: Beam Interactions with Materials and Atoms 268(7-8), $1214-1218$.

Repschläger J., Garbe-Schönberg D., Weinelt M., Schneider R., 2017. Holocene evolution of the North Atlantic subsurface transport. Climate of the Past 13, 4333.

Schlitzer R., Anderson R.F., Dodas E.M., Lohan M., Geibert W., Tagliabue A., Bowie A.R., Jeandel C., Maldonado M.T., Landing W.M., 2018. The GEOTRACES Intermediate Data Product 2017. Chemical Geology. 
Schmitt R.W., Bogden P.S., Dorman C.E., 1989. Evaporation minus precipitation and density fluxes for the North Atlantic. Journal of Physical Oceanography 19, 9 1208-1221.

Suess H.E., 1969. Tritium geophysics as an international research project. Science 163, 3874 14051410.

Taylor C.B., 1966. Tritium in southern hemisphere precipitation 1953-1964. Tellus 18, 1 105-131.

Thiele G., Sarmiento J.L., 1990. Tracer dating and ocean ventilation. Journal of Geophysical Research: Oceans 95, C6 9377-9391.

UNSCEAR U.N.S.C.o.t.E.o.A.R., 2000. Sources and effects of ionizing radiation: sources. United Nations Publications.

UNSCEAR U.N.S.C.o.t.E.o.A.R., 2016. Sources and effects of ionizing radiation: sources. United Nations Publications.

Weatherall, P., Marks, K.M., Jakobsson, M., Schmitt, T., Tani, S., Arndt, J.E., Rovere, M., Chayes, D., Ferrini, V. and Wigley, R. (2015) A new digital bathymetric model of the world's oceans. Earth and Space Science 2(8), 331-345.

Weiss W., Roether W., Dreisigacker E., 1979. Tritium in the North Atlantic Ocean. Inventory, input and transfer into deep water, Behaviour of tritium in the environment.

Weiss W., Roether W., 1980. The rates of tritium input to the world oceans. Earth and Planetary Science Letters 49, 2 435-446. http://dx.doi.org/10.1016/0012-821X(80)90084-9. 